\title{
Health Benefits of Green Banana Consumption: A Systematic Review
}

\author{
Ana Luisa Falcomer ${ }^{1}{ }^{\circledR}$, Roberta Figueiredo Resende Riquette ${ }^{2}$, Bernardo Romão de Lima ${ }^{1}$, \\ Verônica C. Ginani ${ }^{1}$ and Renata Puppin Zandonadi ${ }^{1, *(1)}$ \\ 1 Faculty of Health Sciences, Department of Nutrition, University of Brasília, Brasilia 70910-900, \\ Distrito Federal, Brazil; anafalcomer@gmail.com (A.L.F.); bernardolima156@gmail.com (B.R.d.L.); \\ vcginani@gmail.com (V.C.G.) \\ 2 Campus Oeste Liliane Barbosa, Department of Nutrition, Instituto de Ensino Superior de Brasília (IESB), \\ Brasilia 72225-315 Distrito Federal, Brazil; rriquette@hotmail.com \\ * Correspondence: renatapz@yahoo.com.br; Tel.: +55-61-98103-3600
}

Received: 11 April 2019; Accepted: 23 May 2019; Published: 29 May 2019

\begin{abstract}
Despite the growing demand for green banana (GB) products, there is no review study regarding their potential health benefits. We aimed to compare the health benefits among different GB products by a systematic review. We researched six electronic databases (PubMed, EMBASE, Scopus, Science Direct, Web of Science, and Google Scholar) from inception to March 2019. We found 1009 articles in these databases. After duplicate removal, we screened 732 articles' titles and abstracts, and selected 18 potentially relevant studies for full-text reading. We added five records from the reference list of the fully-read articles and seven suggested by the expert. Twelve articles were excluded. In the end, 18 studies were considered for this systematic review. Ten studies were conducted with green banana flour and eight with the green banana pulp/biomass. Most of the GB health benefits studied were related to the gastrointestinal symptoms/diseases, followed by the glycemic/insulin metabolism, weight control, and renal and liver complications associated to diabetes. Only one study did not confirm the health benefit proposed. It is necessary to standardize the GB dose/effect to different age groups and different health effects considering the GB variety and ripeness level. Further studies are necessary to present better detailing of GB product and their health effects considering all the raw-material characteristics.
\end{abstract}

Keywords: Green banana biomass; green banana flour; unripe banana; health effects

\section{Introduction}

Fruits are essential components of a healthy diet due to their content of vitamins and minerals, fiber, and beneficial non-nutrient substances as bioactive compounds. The World Health Organization (WHO) recommend ingestion of at least $400 \mathrm{~g}$ (about five portions) of fruits and vegetables per day [1]. Low fruit consumption is one of the main risk factors for increased mortality also increases the risk of chronic diseases and poor health quality. Therefore, the regular consumption of fruits can reduce the incidence of some diseases such as diabetes, cardiovascular and gastrointestinal diseases, and some types of cancer [2,3].

Banana (Musa sp.) is one of the most cultivated tropical fruit in the world. Worldwide more than 1000 varieties of bananas are produced. The most commercialized is the Musa Cavendish (about $45 \%$ of global banana market), due to its high production per hectare and its less prone to damage from environmental changes. The other large variety group of banana is the plantain (that has upwards of 100 cultivars) [4]. The banana varieties production corresponds to about $15 \%$ of the world's total fresh fruit produced [5] reaching about 110 million tons of bananas per year [4]. 
However, almost one-third of all bananas gathered is lost since the population mostly consume ripe bananas, and it is a climacteric fruit. Ripe bananas are prone to mechanical damage and are perishable during the maturation process, which makes their storage and transport difficult [6]. Almost $20 \%$ of banana production is not commercialized due to size and appearance flaws, increasing their loss [7]. Therefore, fruit processing emerged aiming to solve problems such as the weak infrastructure, inadequate transportation, and perishable nature of the production, therefore the grower sustains substantial losses. During the post-harvest glut, the loss is considerable, and often, some of the production must be allowed to rot [8]. The optimization of banana processing has been studied to reduce the production of the waste (annual rejection is about $1 / 4$ of the banana fruit) and to improve the bioavailability and utilization of nutrients available in this fruit, highlighting the use of green banana (GB) products $[6,9,10]$.

The consumption of GB products is booming due to their nutritional potential and physiological benefits to human health [10]. Commercial standard color charts classify the stages of banana maturation (Stage $1=$ all green, $2=$ green with a trace of yellow, $3=$ more green than yellow, $4=$ more yellow than green, $5=$ yellow with a trace of green, $6=$ full yellow, $7=$ full yellow with brown spots) $[11,12]$. The green banana is commonly used as stages 1 and 2 of maturation (until 9 weeks; $\mathrm{L}^{*}$ ranging from 56 to 68 , $\mathrm{a}^{*}$ ranging from -20 to -15 , and $\mathrm{b}^{*}$ ranging from 33 to 38) [13-17]. Green bananas seem to be a good source of fibers, vitamins (Vit C, B6, provitamin A), minerals (potassium, phosphorus, magnesium, zinc), bioactive compounds such as phenolic compounds, and resistant starch (RS) [18-24], potentially contributing to health benefits [10,25-29], classifying GB as functional food [9].

However, people do not usually consume the fresh green banana, mainly due to the typical hardness and its high astringency, caused by the presence of soluble phenolic compounds as tannins [30]. Therefore, studies have been using different GB derivate products such as flour [31,32], and green banana biomass (GBB) [33-35]. Despite the growing worldwide demand for GB products [35-38], there is no review study regarding the potential health benefits of GB and its derivatives. Therefore, this study aimed to compare the health benefits among different GB derivate products by a systematic review.

\section{Materials and Methods}

Preferred Reporting Items for Systematic Reviews and Meta-Analyses (PRISMA) Checklist [39], and Guidance of the European Food Safety Authority [40] were used to conduct this systematic review.

\subsection{Protocol and Registration}

The protocol study was not recorded in PROSPERO (an international database of prospectively registered systematic reviews in health and social care, welfare, public health, education, crime, justice, and international development, where there is a health related outcome) since this platform is not destined to reviews with food as the main subject.

\subsection{Eligibility Criteria}

\subsubsection{Inclusion Criteria}

Experimental studies that evaluated the health benefits of green banana consumption were included without language, time, and study restrictions. Despite the absence of language restriction to the abstract, main text, and keywords, the search strategy was performed in English language databases.

\subsubsection{Exclusion Criteria}

We applied the following exclusion criteria: (i) reviews, letters, conference summaries, case reports, short communications, and books; (ii) studies of green banana mixed with another ingredient; (iii) studies that did not analyze the health benefits of green banana consumption. 


\subsection{Information Sources}

Detailed individual search strategies were developed for each database (Web of Science, Pubmed, Embase, and Scopus). We used the Google Scholar platform to research the gray literature. The final databases search occurred on March 28th, 2019. The lists of references of manuscripts selected for full-text reading were manually examined by two independent researchers for potentially relevant studies that could have been lost during the search of the databases.

\subsection{Search Strategy}

We selected and adapted the appropriate combinations of truncation, and words for the search in each database (Appendix A). We managed all references using Endnote Web and Rayyan software and removed duplicate hits.

\subsection{Study Selection}

We conducted the selection in two phases. In the first phase, two reviewers (ALF and RFRR) independently reviewed the titles and abstracts of all manuscripts identified from databases. The reviewers discarded the articles that did not meet the eligibility criteria. In the second phase, the reviewers (ALF and RFRR) applied the eligibility criteria to the full texts of the selected articles. In the two phases, in cases of disagreement, the issue was discussed until a consensus was obtained. In cases that there was no consensus, the final decision was made by the third reviewer (BRL). The complete text of the manuscripts were considered to the final selection. The RFRR examiner critically evaluated the list of references of the selected studies. After this phase, two reviewers (ALF and RFRR) extracted data from the manuscripts. The third examiner (BRL) and experts (VCG and RPZ) added additional studies.

\subsection{Data Collection Process}

We collected the following information from the studies: Authors and year of publication, country of the research, the aim of the study, methods, primary results, nutritional characteristics evaluated, and the type and maturation level of the banana. Calibration exercises were conducted before starting the review process to guarantee consistency among reviewers.

Three reviewers (ALF, RFRR, and BRL) synthesized the data collected using a standardized table containing: Reference; country; aim; study outline; type of method applied; analysis method; banana product analyzed; nutritional composition; health benefit analyzed; population analyzed; number of samples analyzed (total); and result regarding presence of health benefit (yes/no).

\subsection{Risk of Bias}

We used Meta-analysis of Statistics Assessment and Review Instrument (MASTARI) protocol (Joanna Briggs Institute 2014) to evaluate the risk of bias in the manuscripts. The bias risk assessment instrument included eight questions:

1. Were the analyzed products characterized in detail?

2. Was the method of health benefit association analysis specified?

3. Was the method used certified/validated by Codex and/or AOAC?

4. Was the result of health benefit determined quantitatively?

5. Were the methods of consumption of green banana or sample homogenization of the study samples described?

6. Was the experimental design appropriate?

7. Was the statistical analysis adequate to the purpose of the study?

8. Did the results answer the main question? 
The risk of bias was categorized (Appendix B) as "High" when the study reached up to $49 \%$ score "yes"; "Moderate", when the study reached 50\% to 69\% score "yes"; and "Low", when the study reached more than $70 \%$ score "yes".

\section{Results and Discussion}

Initially, we identified a total of 1009 articles in the electronic databases. After duplicate removal, we screened the titles and abstracts of 732 articles, and 18 potentially relevant studies were included for full-text reading. An additional five records were selected from the reference list of the fully-read articles and seven suggested by the expert. We excluded 12 articles after fully-reading (Appendix C). Finally, 18 studies met the inclusion criteria and were included in this systematic review. Figure 1 shows the steps of study identification, screening, and inclusion process of the manuscripts.

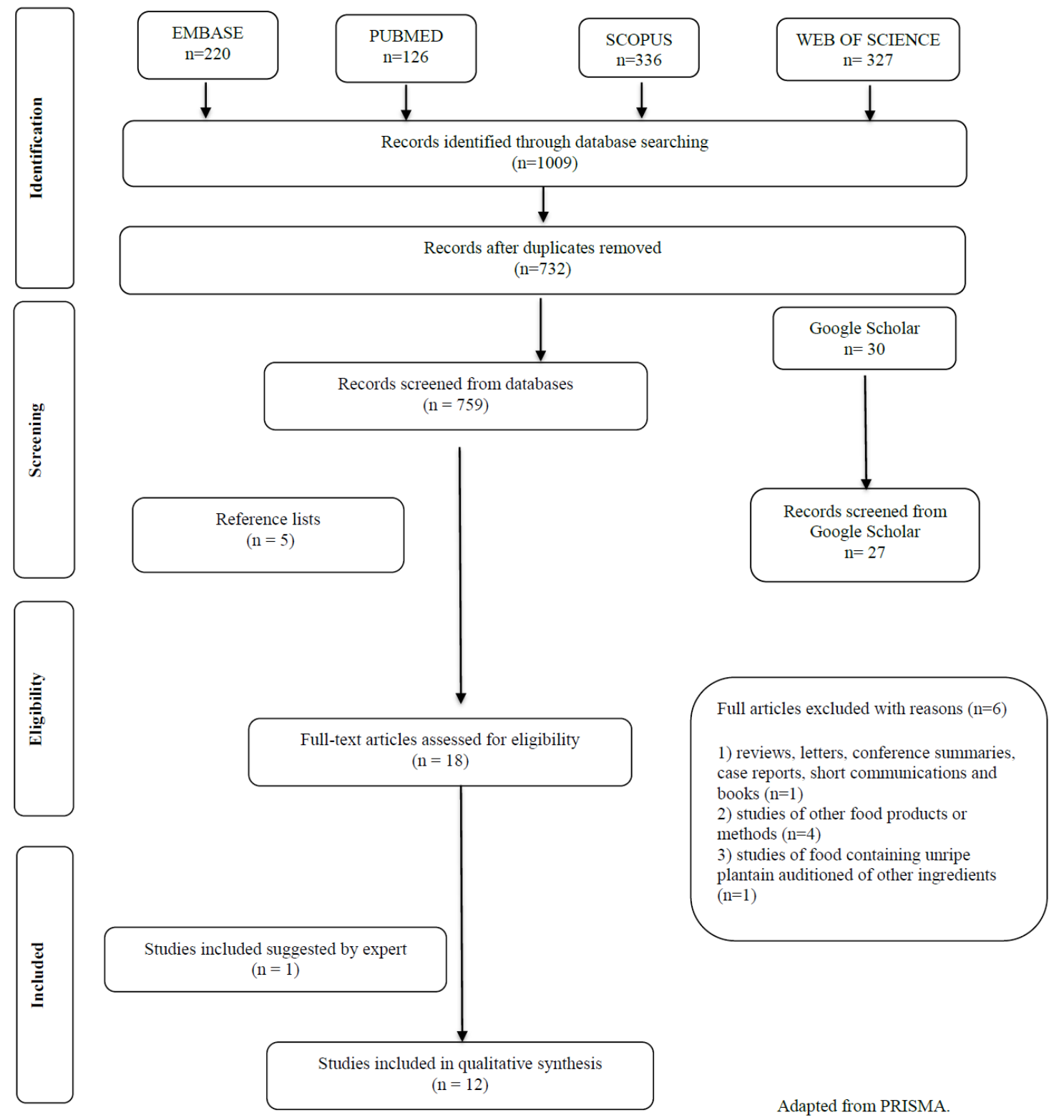

Figure 1. Flow Diagram of Manuscripts screening and inclusion process.

\subsection{Studies General Characteristics}

The studies occurred in nine different countries: England [41], Sweden [42,43], Bangladesh [44-46], Jamaica [47], Venezuela [48], Mexico [49], Brazil [50-54], Nigeria [55], and India [56] (Supplementary 
file Figure S1) between 1984 and 2019 (Table 1). Almost 40\% $(n=7)$ of the studies were conducted in Brazil [50-54], probably due to the Brazilian banana production corresponding for about $15 \%$ of the worldwide banana production. Brazil reportedly has one of the highest banana per capita consumption (about $60 \mathrm{~kg} /$ year) [4,57]. Latin America countries are the biggest banana exporters, and the European countries and the United States are the biggest importers [58]. It is noteworthy that only $15 \%$ of banana production is traded in the international market; the rest is locally consumed, contributing largely to people's diets [4]. Despite the large consumption of bananas in the United States, none were performed there, probably because the product is imported (with little or no local production) and they have access only to ripe bananas [4].

Regarding the ingredients or foods used in the research, ten studies were conducted with green banana flour $[41,43,49-53,55,56,59]$ and eight with the green banana pulp/biomass $[42,44-48$, 54,60]. Most of the studies used green banana flour, probably due to the highest shelf-life and stability of the product compared to the green banana pulp/biomass [61], and this product is well characterized in the scientific literature. However, this product tends to be expensive and not accessible in some countries [10,32,36,62-72], stimulating the utilization of green banana pulp/biomass in some products. Considering the type of research method, 14 of the studies were performed in vivo $[41,42,44-49,51,52,54,55,59,60]$, one conducted in vitro [56], and three studies used both in vivo and in vitro methods $[43,50,53]$.

The study population was diverse. Of the in vivo studies, five were performed with rats [41,42,53,55,59] and 12 with humans, five with children and adolescents [44-46,48,54] and seven with adults $[43,47,49-52,60]$, both healthy and unhealthy individuals (persistent diarrhea, constipation, diabetes, overweight, and obesity), showing health benefits in different age groups. Most of the studies analyzed were performed under experimental design, a randomized clinical trial $(n=16)$. The characteristics of the studies in chronological order is detailed in Table 1. 
Table 1. Descriptive characteristics and outcomes of interest of the included studies.

\begin{tabular}{|c|c|c|c|c|c|c|c|}
\hline Author/year & Country & Aim & Study Outline & Analysis Method & $\begin{array}{l}\text { GB }^{*} \text { product }\left(\mathrm{GBF}^{* *},\right. \\
\text { GBP }^{* * * *} \text { or GBB } \\
\text { AND } \\
\text { Health Benefit Analyzed }\end{array}$ & $\begin{array}{l}\text { Population } \\
\text { Analyzed }\end{array}$ & $\begin{array}{l}\text { Heath Benefi } \\
\text { Confirmation } \\
\text { (Yes or No) }\end{array}$ \\
\hline $\begin{array}{l}\text { Best, Lewis and } \\
\text { Nasser (1984) } \\
\text { [41] }\end{array}$ & England & $\begin{array}{l}\text { To check the anti-ulcerogenic } \\
\text { activity of the unripe plantain } \\
\text { banana. }\end{array}$ & $\begin{array}{l}\text { Experimental } \\
\text { study, randomized } \\
\text { clinical trial }\end{array}$ & $\begin{array}{l}\text { In vivo } \\
\text { Extracts of Banana flour were assessed for } \\
\text { biological activity against ulceration } \\
\text { (prophylactic or curative). }\end{array}$ & $\begin{array}{l}\text { GBF } \\
\text { Exercise anti-ulcerogenic } \\
\text { activity }\end{array}$ & $\begin{array}{l}14 \text { male rats with } \\
\text { ulcer }\end{array}$ & Yes \\
\hline $\begin{array}{l}\text { Dunjic et al. } \\
\text { (1993) [42] }\end{array}$ & Sweden & $\begin{array}{l}\text { To evaluate the protective } \\
\text { capacities of GB and their } \\
\text { potentially active against acute } \\
\text { and chronic gastric mucosal } \\
\text { lesions. }\end{array}$ & $\begin{array}{l}\text { Experimental } \\
\text { study, randomized } \\
\text { clinical trial }\end{array}$ & $\begin{array}{l}\text { In vivo } \\
\text { GBP was mixed with saline or pectin and } \\
\text { phosphatidylcholine solution and given by } \\
\text { gavage, as a pretreatment in a single dose. }\end{array}$ & $\begin{array}{l}\text { GBP } \\
\text { Protection of gastric mucosa } \\
\text { against experimentally } \\
\text { induced injuries in rats }\end{array}$ & $\begin{array}{l}121 \text { male rats with } \\
\text { an injury to the } \\
\text { stomach }\end{array}$ & Yes \\
\hline $\begin{array}{l}\text { Rabbani et al. } \\
\text { (2001) [44] }\end{array}$ & Bangladesh & $\begin{array}{l}\text { To evaluate the therapeutic effects } \\
\text { of GB in children with persistent } \\
\text { diarrhea. }\end{array}$ & $\begin{array}{l}\text { Experimental } \\
\text { study, randomized } \\
\text { clinical trial }\end{array}$ & $\begin{array}{l}\text { In vivo } \\
\text { In a double-blind trial, boys were } \\
\text { randomly given a rice-based diet } \\
\text { containing either } 250 \mathrm{~g} / \mathrm{L} \text { of cooked GB or } 4 \\
\mathrm{~g} / \mathrm{kg} \text { pectin or the rice-diet alone (control), } \\
\text { for seven days. Stool weight and } \\
\text { consistency, the frequency of vomiting and } \\
\text { purging, and duration of illness were } \\
\text { measured. }\end{array}$ & $\begin{array}{l}\text { GBP } \\
\text { Control of persistent } \\
\text { diarrhea }\end{array}$ & $\begin{array}{l}62 \text { boys (age } 5-12 \\
\text { months) with } \\
\text { persistent diarrhea }\end{array}$ & Yes \\
\hline $\begin{array}{l}\text { Langkilde, } \\
\text { Champ, and } \\
\text { Andersson (2002) } \\
{[43]}\end{array}$ & Sweden & $\begin{array}{l}\text { To evaluate how } \mathrm{RS}^{* * * * *} \\
\text { influences small-intestinal } \\
\text { absorption of nutrients, sterol } \\
\text { metabolism and colonic } \\
\text { fermentation }\end{array}$ & $\begin{array}{l}\text { Experimental } \\
\text { study, randomized } \\
\text { clinical trial }\end{array}$ & $\begin{array}{l}\text { In vitro e in vivo } \\
10 \text { ileostomy subjects received a controlled } \\
\text { diet with } 30 \mathrm{~g} \text { raw GBF or cooked GBF in } \\
\text { random order. After, } 7 \text { ileostomy subjects } \\
\text { received a plant-polysaccharide-free diet } \\
\text { with the addition of } 30 \mathrm{~g} \text { GBF. }\end{array}$ & $\begin{array}{l}\text { GBF } \\
\text { Knowledge of how RS } \\
\text { influences small-intestinal } \\
\text { absorption of nutrients, } \\
\text { sterol metabolism and } \\
\text { colonic fermentation }\end{array}$ & $\begin{array}{l}10 \text { ileostomized } \\
\text { adults (male } 50 \% \text {; } \\
\text { age } 28-70 \text { years) }\end{array}$ & Yes \\
\hline $\begin{array}{l}\text { Rabbani et al. } \\
\text { (2004) [45] }\end{array}$ & Bangladesh & $\begin{array}{l}\text { To evaluate whether the effects of } \\
\text { GB and pectin were associated } \\
\text { with improvement of the small } \\
\text { bowel mucosal permeability in } \\
\text { children with persistent diarrhea }\end{array}$ & $\begin{array}{l}\text { Experimental } \\
\text { study, randomized } \\
\text { clinical trial }\end{array}$ & $\begin{array}{l}\text { In vivo } \\
\text { Boys with persistent diarrhea (14 days) } \\
\text { received week's treatment with a } \\
\text { rice-based diet containing either cooked } \\
\text { GB, pectin, or rice diet alone. Intestinal } \\
\text { permeability was assessed before and after } \\
\text { treatment. }\end{array}$ & $\begin{array}{l}\text { GBP } \\
\text { Control of persistent } \\
\text { diarrhea }\end{array}$ & $\begin{array}{l}57 \text { boys }(5-12 \\
\text { months) with } \\
\text { persistent diarrhea } \\
\text { (14 days) }\end{array}$ & Yes \\
\hline $\begin{array}{l}\text { Bahado-Singh et } \\
\text { al. (2006) [47] }\end{array}$ & Jamaica & $\begin{array}{l}\text { To determine the Glicemic Index } \\
\text { (GI) of some commonly eaten } \\
\text { Caribbean carbohydrate-rich } \\
\text { foods, processed by different } \\
\text { traditional cooking methods. }\end{array}$ & $\begin{array}{l}\text { Experimental } \\
\text { study, randomized } \\
\text { clinical trial }\end{array}$ & $\begin{array}{l}\text { In vivo } \\
\text { GI values for } 14 \text { commonly eaten } \\
\text { carbohydrate-rich foods processed by } \\
\text { various methods were determined using } \\
\text { ten healthy subjects. Pure glucose was } \\
\text { used as the standard with a GI value of } 100 \text {. }\end{array}$ & $\begin{array}{l}\text { GB } \\
\text { Knowledge of GB glycemic } \\
\text { Index. } \\
\text { GB presented Low glycemic } \\
\text { index when boiled or fried. }\end{array}$ & $\begin{array}{l}10 \text { healthy adults } \\
\text { (non-diabetic, } \\
18-40 \text { years) }\end{array}$ & Yes \\
\hline
\end{tabular}


Table 1. Cont.

\begin{tabular}{|c|c|c|c|c|c|c|c|}
\hline Author/year & Country & Aim & Study Outline & Analysis Method & $\begin{array}{l}\text { GB }^{*} \text { product }\left(\mathrm{GBF}^{* *},\right. \\
\text { GBP }^{* * *} \text { or GBB } \\
\text { AND } \\
\text { Health Benefit Analyzed }\end{array}$ & $\begin{array}{l}\text { Population } \\
\text { Analyzed }\end{array}$ & $\begin{array}{l}\text { Heath Benefit } \\
\text { Confirmation } \\
\text { (Yes or No) }\end{array}$ \\
\hline $\begin{array}{l}\text { Álvarez-Acosta } \\
\text { et al. (2009) [48] }\end{array}$ & Venezuela & $\begin{array}{l}\text { To evaluate the beneficial effects } \\
\text { of GB based diet on stool volume, } \\
\text { frequency and weight gain as } \\
\text { compared with a traditional } \\
\text { yogurt-based diet in children } \\
\text { with persistent diarrhea. }\end{array}$ & $\begin{array}{l}\text { Experimental } \\
\text { study, randomized } \\
\text { clinical trial }\end{array}$ & $\begin{array}{l}\text { In vivo } \\
\text { Prospective, in-hospital controlled trial in } \\
\text { children who had experienced } 14 \text { days of } \\
\text { persistent diarrhea. Two groups of } 40 \\
\text { individuals received isocaloric (100 } \\
\mathrm{kcal} / \mathrm{kg} / \mathrm{d} \text { ) diets: } 1 \text { ) a-week treatment } \\
\text { consisting of a } 50 \mathrm{~g} / \mathrm{L} \text { of cooked GB-based } \\
\text { diet. 2) The control group was fed on a } \\
\text { yogurt-based diet. }\end{array}$ & $\begin{array}{l}\text { GBP } \\
\text { Control of persistent } \\
\text { diarrhea }\end{array}$ & $\begin{array}{l}80 \text { children of both } \\
\text { gender with ages } \\
\text { ranging from } 1 \text { to } \\
28 \text { months, with } \\
\text { persistent diarrhea } \\
\text { (14 days). }\end{array}$ & Yes \\
\hline $\begin{array}{l}\text { Rabbani et al. } \\
\text { (2010) [46] }\end{array}$ & Bangladesh & $\begin{array}{l}\text { To determine the effectiveness of } \\
\text { adding GB to conventional } \\
\text { household diets in the } \\
\text { management of childhood } \\
\text { diarrhea (reducing the duration) }\end{array}$ & $\begin{array}{l}\text { Experimental } \\
\text { study, randomized } \\
\text { clinical trial }\end{array}$ & $\begin{array}{l}\text { In vivo } \\
\text { Individuals were randomly assigned to } \\
\text { either a standard care group or standard } \\
\text { care plus GB group (mothers were } \\
\text { instructed to add a cooked GB to the diets } \\
\text { of diarrheal children. Through a } \\
\text { village-based surveillance system, } \\
\text { diarrheal morbidity data (severity, } \\
\text { duration, and compliance) were collected } \\
\text { for } 14 \text { days. }\end{array}$ & $\begin{array}{l}\text { GBP } \\
\text { Treatment of diarrhea acute } \\
\text { and prolonged in children }\end{array}$ & $\begin{array}{l}2968 \text { Bangladeshi } \\
\text { rural children 6-36 } \\
\text { months old with } \\
\text { diarrhea }\end{array}$ & Yes \\
\hline $\begin{array}{l}\text { Menezes et al. } \\
\text { (2010) [50] }\end{array}$ & Brazil & $\begin{array}{l}\text { To study the in vitro colonic } \\
\text { fermentation profile of } \\
\text { unavailable carbohydrates of two } \\
\text { different kinds of GBF and to } \\
\text { evaluate their postprandial } \\
\text { glycemic responses. }\end{array}$ & $\begin{array}{l}\text { Experimental } \\
\text { study, randomized } \\
\text { clinical trial }\end{array}$ & $\begin{array}{l}\text { In vitro and in vivo } \\
\text { The fermentability of the flours was } \\
\text { evaluated by different parameters, using } \\
\text { rat inoculum, as well as the glycemic } \\
\text { response produced after the ingestion by } \\
\text { healthy volunteers. }\end{array}$ & $\begin{array}{l}\text { GBF, GBB, and GB starch } \\
\text { To present high in vitro } \\
\text { fermentability without } \\
\text { increasing postprandial } \\
\text { glycemic response in } \\
\text { healthy subjects }\end{array}$ & $\begin{array}{l}18 \text { healthy adults } \\
\text { aged } 22-40 \text { years }\end{array}$ & Yes \\
\hline
\end{tabular}


Table 1. Cont

\begin{tabular}{|c|c|c|c|c|c|c|c|}
\hline Author/year & Country & Aim & Study Outline & Analysis Method & $\begin{array}{l}B^{*} \text { product }\left(\mathrm{GBF}^{* *},\right. \\
\text { GBP } \\
\text { AND } \\
\text { Health Benefit Analyzed }\end{array}$ & $\begin{array}{l}\text { Population } \\
\text { Analyzed }\end{array}$ & $\begin{array}{l}\text { Heath Benefit } \\
\text { Confirmation } \\
\text { (Yes or No) }\end{array}$ \\
\hline $\begin{array}{l}\text { Silva et al. (2014) } \\
\text { [51] }\end{array}$ & Brazil & $\begin{array}{l}\text { To evaluate the effects of GBF } \\
\text { consumption on anthropometric } \\
\text { and biochemical parameters in } \\
\text { overweight women. }\end{array}$ & $\begin{array}{l}\text { Experimental } \\
\text { study, randomized } \\
\text { clinical trial }\end{array}$ & $\begin{array}{l}\text { In vivo } \\
\text { The GI of GBF in the study was } \\
\text { determined. The effects of consumption of } \\
20 \text { g of GBF/day on weight, body mass } \\
\text { index, blood pressure, waist and hip } \\
\text { circumference, body composition, } \\
\text { hemoglobin, lipid profile, glucose, insulin, } \\
\text { insulin resistance, liver function, and } \\
\text { energy intake were evaluated in } \\
\text { overweight women for } 45 \text { days. }\end{array}$ & $\begin{array}{l}\text { GBF } \\
\text { Improve anthropometric } \\
\text { and biochemical parameters } \\
\text { with GBF consumption }\end{array}$ & $\begin{array}{l}25 \text { women adults } \\
\text { overweight }\end{array}$ & Yes \\
\hline $\begin{array}{l}\text { Silva et al. (2015) } \\
\text { [52] }\end{array}$ & Brazil & $\begin{array}{l}\text { To analyze the effects of } \\
\text { consumption of GBF in body } \\
\text { weight, lipid profile, } \\
\text { inflammatory parameters and } \\
\text { food consumption in overweight } \\
\text { adult women. }\end{array}$ & $\begin{array}{l}\text { Experimental } \\
\text { study, randomized } \\
\text { clinical trial }\end{array}$ & $\begin{array}{l}\text { In vivo } \\
25 \text { adult overweight women consumed } \\
\text { daily } 20 \text { g of GBF for } 45 \text { days. The study } \\
\text { protocol included anthropometric } \\
\text { measurements, body composition, food } \\
\text { intake, lipid profile, and determination of } \\
\text { serum inflammatory parameters. }\end{array}$ & $\begin{array}{l}\text { GBF } \\
\text { The consumption of GBF } \\
\text { alters weight, body } \\
\text { composition, lipid profile, } \\
\text { and inflammatory } \\
\text { parameters. }\end{array}$ & $\begin{array}{l}25 \text { women adults } \\
\text { overweight }\end{array}$ & No \\
\hline $\begin{array}{l}\text { Eleazu and } \\
\text { Okafor (2015) } \\
\text { [55] }\end{array}$ & Nigeria & $\begin{array}{l}\text { To investigate the effect of GB on } \\
\text { markers of hepatic dysfunction in } \\
\text { streptozotocin-induced diabetic } \\
\text { rats. }\end{array}$ & $\begin{array}{l}\text { Experimental } \\
\text { study, randomized } \\
\text { clinical trial }\end{array}$ & $\begin{array}{l}\text { In vivo } \\
\text { Blood glucose; relative liver weight; } \\
\text { relative kidney weight; relative heart } \\
\text { weight; relative pancreatic weight; AST, } \\
\text { ALT, and alkaline phosphatase; serum } \\
\text { amylase, lipase, total, and conjugated } \\
\text { bilirubin; and chemical analysis of the test } \\
\text { feed were determined using standard } \\
\text { techniques. }\end{array}$ & $\begin{array}{l}\text { GBF } \\
\text { Amelioration of renal and } \\
\text { liver complications arising } \\
\text { from diabetes mellitus }\end{array}$ & $\begin{array}{l}42 \text { diabetic and } 6 \\
\text { non-diabetic rats }\end{array}$ & Yes \\
\hline $\begin{array}{l}\text { Dan et al. (2015) } \\
\text { [53] }\end{array}$ & Brazil & $\begin{array}{l}\text { To evaluate the effect of the } \\
\text { colonic fermentation of } \\
\text { unavailable carbohydrates from } \\
\text { unripe banana (mass - UBM - and } \\
\text { starch - UBS) over parameters } \\
\text { related to glucose and insulin } \\
\text { response in rats. }\end{array}$ & $\begin{array}{l}\text { Experimental } \\
\text { study, randomized } \\
\text { clinical trial }\end{array}$ & $\begin{array}{l}\text { In vivo and in vitro } \\
\text { Wistar male rats were fed either a control } \\
\text { diet, a UBM diet ( } 5 \% \text { resistant starch - RS) } \\
\text { or a UBS diet }(10 \% \text { RS) for } 28 \text { days. In vivo } \\
\text { (oral glucose tolerance test) and in vitro } \\
\text { (cecum fecal fermentation, pancreatic islet } \\
\text { insulin secretion) analyses were } \\
\text { performed. }\end{array}$ & $\begin{array}{l}\text { GBF, and GB starch } \\
\text { Promote colonic } \\
\text { fermentation and influence } \\
\text { glycemic control, improving } \\
\text { insulin sensitivity in rats. }\end{array}$ & $\begin{array}{l}48 \text { healthy male } \\
\text { rats }\end{array}$ & Yes \\
\hline
\end{tabular}


Table 1. Cont

\begin{tabular}{|c|c|c|c|c|c|c|c|}
\hline Author/year & Country & Aim & Study Outline & Analysis Method & $\begin{array}{l}\text { GB }^{*} \text { product }\left(\mathrm{GBF}^{* *},\right. \\
\text { GBP }^{* * *} \text { or GBB } \\
\text { AND } \\
\text { Health Benefit Analyzed }\end{array}$ & $\begin{array}{l}\text { Population } \\
\text { Analyzed }\end{array}$ & $\begin{array}{l}\text { Heath Benefit } \\
\text { Confirmation } \\
\text { (Yes or No) }\end{array}$ \\
\hline $\begin{array}{l}\text { Sardá et al. } \\
\text { (2016) [60] }\end{array}$ & Brazil & $\begin{array}{l}\text { To evaluate the impact of regular, } \\
\text { but non-daily, intake of RS from } \\
\text { GBF on parameters related to } \\
\text { hunger/satiety and glucose } \\
\text { homeostasis in healthy } \\
\text { volunteers. }\end{array}$ & $\begin{array}{l}\text { Experimental } \\
\text { study, randomized } \\
\text { clinical trial }\end{array}$ & $\begin{array}{l}\text { In vivo } \\
\text { Healthy volunteers consumed GBF, rich in } \\
\text { resistant starch ( } 5 \mathrm{~g} / 8 \mathrm{~g} \text { GBF), nondaily ( } 3 \\
\text { times a week) for six weeks. The } \\
\text { parameters hunger and satiety were } \\
\text { evaluated by the visual analog scale and } \\
\text { area under the curve of ghrelin and } \\
\text { peptide YY hormones. }\end{array}$ & $\begin{array}{l}\text { GBF } \\
\text { Decrease hunger, increase } \\
\text { satiety, and glucose } \\
\text { homeostasis }\end{array}$ & $\begin{array}{l}22 \text { healthy adults } \\
(27.6 \pm 5.1 \text { years })\end{array}$ & Yes \\
\hline $\begin{array}{l}\text { Silva et al. (2016) } \\
\text { [59] }\end{array}$ & Brazil & $\begin{array}{l}\text { To investigate the effects of a GBP } \\
\text { diet on the oxidative damage } \\
\text { from type } 1 \text { diabetes mellitus } \\
\text { (DM) }\end{array}$ & $\begin{array}{l}\text { Experimental } \\
\text { study, randomized } \\
\text { clinical trial }\end{array}$ & $\begin{array}{l}\text { In vivo } \\
\text { Formulations containing } 25,50 \text {, and } 75 \% \text { of } \\
\text { GBP were included in a } 12 \text {-week diet of } \\
\text { Wistar rats with type } 1 \text { DM. They evaluated } \\
\text { preventing oxidative damage in kidneys } \\
\text { and liver homogenates of rats were } \\
\text { evaluated using the TBARS and DNPH } \\
\text { assay fasting glycemia, fructosamine levels, } \\
\text { renal function, liver function, and lipid } \\
\text { profile in the serum of rats. }\end{array}$ & $\begin{array}{l}\text { GBP } \\
\text { To prevent oxidative } \\
\text { damage in liver and kidney } \\
\text { and improves biochemical } \\
\text { parameters in type } 1 \\
\text { diabetic rats }\end{array}$ & $\begin{array}{l}60 \text { rats with and } \\
\text { without diabetes }\end{array}$ & Yes \\
\hline $\begin{array}{l}\text { Arun et al. (2017) } \\
\text { [56] }\end{array}$ & India & $\begin{array}{l}\text { To evaluate the antidiabetic } \\
\text { potential of Musa paradisiaca } \\
\text { (plantain) }\end{array}$ & $\begin{array}{l}\text { Experimental } \\
\text { cross-sectional } \\
\text { study }\end{array}$ & $\begin{array}{l}\text { In vitro } \\
\text { Were analyzed soluble and insoluble } \\
\text { dietary fiber, glucose and cholesterol } \\
\text { adsorption capacity and the ethyl acetate } \\
\text { and methanol extracts were analyzed for } \\
\text { phenolics content, antioxidant activities, } \\
\text { antidiabetic, and cardiovascular protection } \\
\text { efficacy. }\end{array}$ & $\begin{array}{l}\text { GBF } \\
\text { Ameliorates type } 2 \text { diabetes } \\
\text { and associated } \\
\text { cardiovascular risks }\end{array}$ & - & Yes \\
\hline $\begin{array}{l}\text { Cassettari et al. } \\
\text { (2019) [54] }\end{array}$ & Brazil & $\begin{array}{l}\text { To evaluate the effect of } \\
\text { combinations of GBB and } \\
\text { laxatives in children and } \\
\text { adolescents with chronic } \\
\text { constipation }\end{array}$ & $\begin{array}{l}\text { Prospective, } \\
\text { interventional, } \\
\text { randomized } \\
\text { clinical study }\end{array}$ & $\begin{array}{l}\text { In vivo } \\
\text { It was a randomized study of } 80 \text { children } \\
\text { and adolescents with functional } \\
\text { constipation divided into } 5 \text { groups: (1) } \\
\text { GBB alone; (2) GBB plus PEG } 3350 \text { with } \\
\text { electrolytes; (3) GBB plus sodium } \\
\text { pyrosulfate; (4) PEG } 3350 \text { with electrolytes } \\
\text { alone; and (5) sodium picosulfate alone. }\end{array}$ & $\begin{array}{l}\text { GBP } \\
\text { To ameliorate the symptoms } \\
\text { of chronic intestinal } \\
\text { constipation and decrease } \\
\text { the use of laxatives. }\end{array}$ & $\begin{array}{l}80 \text { children and } \\
\text { adolescents (5-15 } \\
\text { years) with } \\
\text { functional } \\
\text { constipation }\end{array}$ & Yes \\
\hline
\end{tabular}




\subsection{Nutritional Composition of Green Banana Derivatives, Health Benefits, and Total Amount Used in the Studies}

Table 2 presents the type and the amount of green banana used and the composition of green banana products found in each study. In the Alvarez-Acosta et al. [48] study, the authors did not present the composition of the GB product used. Therefore, it is not presented in Table 2.

The studies presented different types of analyses regarding the composition of the green banana product offered (Table 2). It is necessary to emphasize that the food composition like fruits tend to vary according to the soil, climate, banana variety, maturation stage, local of production, and other factors which can explain the significant difference between the results found in the studies regarding the product composition. People tend to use the green banana products due to the claim that they present about of $60-80 \%$ of their carbohydrates as indigestible carbohydrates (resistant starch, cellulose, hemicelluloses, and lignin) [30,73]. Also, the green banana flour has been highlighted due to its content of resistant starch, making its use attractive for food preparation where starch is the basis. Resistant starch (RS) has the advantage on food production of having less impact on the sensory properties of the final products (such as better appearance, texture, and mouthfeel), which is favorable for consumer acceptance [74,75]. However, only five studies evaluated RS in which the amount ranged from $5.5 \mathrm{~g}$ to $16.6 \mathrm{~g}$ of RS in green banana flour [43,50,53]; $34 \mathrm{~g}$ to $67 \mathrm{~g}$ in green banana starch [49,50]; $1.2 \mathrm{~g}$ of RS in cooked green banana flour [43]; and $7.8 \mathrm{~g}$ in green banana pulp [54].

RS can promote health benefits since it is not hydrolyzed in the digestive tract, and it is fermented in the colon, acting similarly to fibers [73]. RS behaves physiologically like fiber reducing glycemia and consequently helping to prevent or treat type 2 diabetes and decreasing the risk of developing chronic diseases [28]. RS also contributes to the prevention of intestinal diseases; to the blood cholesterol levels reduction $[25,76]$; to increase the synthesis of B-complex vitamins and mineral absorption; and to improve the immune response and the prevention of the development of intestinal cancer $[59,74]$. The studies that evaluated the amount of RS in banana flour showed the amount of $5.5 \mathrm{~g}$ to $16.6 \mathrm{~g}$ of RS in $100 \mathrm{~g}$ of green banana flour [43,50,53]. In green banana pulp, the amount was lower (7.8 g/100 g) [54] than found by most of the studies [43,50] with green banana flour. The higher amount of RS in GB flour compared with green banana pulp is expected since GB flour presents low moisture content $(1.6-7.6 \%)$ [77] due to the dehydration process which concentrates solid components without the use of cooking methods. It is also important to highlight that bananas amylopectin structure is different from corn or potato amylopectin, which present more long chains, and banana starch retrogrades faster than corn or potato starch producing less digestible cooked starch $[75,78]$. These findings suggest the benefits of green banana products consumption on diseases linked to digestion and glucose/insulin metabolism $[47,50,53,56,60]$.

Regarding fiber content, the studies presented different analysis. Some of them [50,53,56] analyzed total dietary fiber (DF), insoluble fiber (IF), and soluble fiber (SF) in green banana flours (ranging from $5.7 \mathrm{~g}$ to $10.3 \mathrm{~g}$ of DF; $3.3 \mathrm{~g}$ to $53.3 \mathrm{~g}$ of IF; and $0.0 \mathrm{~g}$ to $12.45 \mathrm{~g}$ of SF, respectively). The only study which evaluated dietary fiber in green banana pulp [54] mentioned the amount of $4.4 \mathrm{~g} / 100 \mathrm{~g}$. The other studies presented the amount of crude fiber $[47,52,55,56,59]$ in flour $(6.77 \mathrm{~g}$ to $65.76 \mathrm{~g} / 100$ g) $[52,55,56]$ and in the green banana pulp $(0.48 \mathrm{~g}$ to $5.52 \mathrm{~g} / 100 \mathrm{~g})[47,59]$. The fiber content of the green banana pulp also tends to be lower than in the green banana flour (GBF) due to the dehydration of the flour $[67,71,77]$. Fiber is considered an important ingredient in the formulation of the functional food, due to its beneficial health effects in gut regulation, satiety, appetite control, glycemic regulation, and cancer prevention) [79]. Besides the health effects, they are functional ingredients used to improve the food products physical and structural properties of oil retention, hydration, viscosity, sensory characteristics, and shelf-life [80]. According to Food and Agriculture Organization of United Nations (FAO) [81], the food is considered a source of DF if the DF content is at least $1.5 \mathrm{~g}$ of fiber per $100 \mathrm{kcal}$ of food, and high in fiber if it contains $3 \mathrm{~g}$ of fiber per $100 \mathrm{kcal}$ of food. Therefore, in some studies, the green banana product could be considered a source of fiber [50,53,54], in addition to the RS content. 
Table 2. Type and the amount of green banana and the composition of green banana products found in each study.

\begin{tabular}{|c|c|c|c|c|c|c|c|c|c|c|c|c|}
\hline Author & $\begin{array}{l}\text { Type of Green } \\
\text { Banana (GB) }\end{array}$ & $\begin{array}{c}\text { Carboydrates } \\
(\%)\end{array}$ & Protein $(\%)$ & $\begin{array}{l}\text { Lipid } \\
(\%)\end{array}$ & Ash (\%) & $\begin{array}{l}\text { Crude } \\
\text { Fiber (\%) }\end{array}$ & $\begin{array}{l}\text { Dietary Fiber } \\
\text { (DF) (\%) }\end{array}$ & $\begin{array}{l}\text { Insoluble } \\
\text { Fiber (\%) }\end{array}$ & $\begin{array}{c}\text { Soluble } \\
\text { Fiber (\%) }\end{array}$ & $\begin{array}{c}\text { Total } \\
\text { Starch }(\%)\end{array}$ & RS $^{c}(\%)$ & Daily Dose (g) \\
\hline \multicolumn{13}{|c|}{ GREEN BANANA FLOUR } \\
\hline Best et al. [41] & $\begin{array}{l}\text { Musa cavendish } \\
\text { and Mondan }\end{array}$ & - & - & - & - & - & - & - & - & - & - & $\begin{array}{l}\text { 1) Prophylaxy: } 5 g \\
\text { 2) Curative: } 7 g\end{array}$ \\
\hline Langkilde et al. [43] & $\mathrm{RBF}^{\mathrm{e}}$ and $\mathrm{CBF}^{\mathrm{f}}$ & - & - & - & - & - & - & - & - & - & $\begin{array}{l}\text { RBF: } 16.3 \\
\text { CBF: } 1.2\end{array}$ & $30 \mathrm{~g}$ \\
\hline Ble-Castillo et al. [49] & $\begin{array}{l}\text { Musa cavendish } \\
\text { AAA }\end{array}$ & $60 \mathrm{DB}^{\mathrm{d}}$ & $\begin{array}{l}1.9 \\
\text { DB }\end{array}$ & $0.4 \mathrm{DB}$ & $\begin{array}{l}0.8 \\
\text { DB }\end{array}$ & - & - & - & - & - & 34 & $24 \mathrm{~g}$ \\
\hline Menezes et al. $[50]^{a}$ & Musa paradisiaca & - & - & - & & - & $\begin{array}{l}\text { UBM g: }^{2} 10.3 \\
\text { UBS }^{\mathrm{h}}: 1.3\end{array}$ & $\begin{array}{l}\text { UBM: } 5.8 \\
\text { UBS: } 0.0\end{array}$ & $\begin{array}{l}\text { UBM: } 4.5 \\
\text { UBS: } 1.3\end{array}$ & $\begin{array}{l}\text { UBM: } 61.6 \\
\text { UBS: } 83.8\end{array}$ & $\begin{array}{l}\text { UBM: } 8.2 \\
\text { UBS: } 67.0\end{array}$ & $\begin{array}{l}59 \mathrm{~g} \text { de UBS } \\
81 \mathrm{~g} \text { de UBM }\end{array}$ \\
\hline Silva et al. [51] & - & - & - & - & - & - & - & - & - & - & - & $20 \mathrm{~g} /$ day (45 days) \\
\hline Silva et al. [52] & - & 65 & 5 & 0.5 & - & 11 & - & - & - & - & - & 20 \\
\hline Eleazu and Okafor [55] ${ }^{b}$ & Musa paradisiaca & 55.6 & 14.7 & 17.59 & - & 6.77 & - & - & - & - & - & - \\
\hline Dan et al. [53] & Musa paradisiaca & $\begin{array}{l}\text { UBM } \mathrm{g}: 63.7 \\
\text { UBS }^{\text {h: }} 64.8\end{array}$ & $\begin{array}{l}\text { UBM: } 19.1 \\
\text { UBS: } 17.8\end{array}$ & $\begin{array}{l}\text { UBM: } 6.8 \\
\text { UBS: } 7.0\end{array}$ & $\begin{array}{l}\text { UBM: } 2.9 \\
\text { UBS: } 4.6\end{array}$ & - & $\begin{array}{l}\text { UBM: } 6.6 \\
\text { UBS: } 5.7\end{array}$ & $\begin{array}{l}\text { UBM: } 3.3 \\
\text { UBS: } 5.7\end{array}$ & $\begin{array}{l}\text { UBM: } 3.3 \\
\text { UBS: } 0.0\end{array}$ & $\begin{array}{l}\text { UBM: } 42 \\
\text { UBS: } 42.8\end{array}$ & $\begin{array}{l}\text { UBM: } 5.5 \\
\text { UBS: } 10.6\end{array}$ & $\begin{array}{l}\text { UBS: } 5 \mathrm{~g} \text { of RS/100 } \mathrm{g} \text { of diet } \\
\text { UBM: } 10 \mathrm{~g} \text { of RS/100 } \mathrm{g} \text { of diet }\end{array}$ \\
\hline Sardá et al. [60] & $\begin{array}{l}\text { Musa acuminata, } \\
\text { Cavendish }\end{array}$ & - & - & - & - & - & - & - & - & - & - & $8 \mathrm{~g}$ \\
\hline Arun et al. [56] & Musa paradisiaca & - & - & - & - & 65.76 & - & 53.31 & 12.45 & - & - & - \\
\hline \multicolumn{13}{|c|}{ GREEN BANANA PULP OR BIOMASS } \\
\hline Dunjic et al. [42] & Musa Cavendish & - & - & $0.1 \mathrm{DB}$ & - & - & - & - & - & - & - & $1.3 \mathrm{~g}$ \\
\hline Rabbani et al. [44] & $\begin{array}{l}\text { Musa paradisiaca } \\
\text { sapientum }\end{array}$ & - & - & - & - & - & - & - & - & - & - & $250 \mathrm{~g}$ \\
\hline Rabbani et al. [45] & $\begin{array}{l}\text { Musa paradisiaca } \\
\text { sapientum }\end{array}$ & - & - & - & - & - & - & - & - & - & - & $30 \mathrm{~g}$ per kg of body weight \\
\hline Bahado-Singh et al. [47] & $\begin{array}{l}\text { Green banana (GB) } \\
\text { Green plantain }\end{array}$ & $\begin{array}{c}\text { GB: } 25.6 \\
\text { Green } \\
\text { plantain: } 28.4\end{array}$ & $\begin{array}{c}\text { GB: } 1.42 \\
\text { Green } \\
\text { plantain: } 1.7\end{array}$ & $\begin{array}{c}\text { GB: } 0.3 \\
\text { Green } \\
\text { plantain: } 0.2\end{array}$ & $\begin{array}{c}\text { GB: } 0.9 \\
\text { Green } \\
\text { plantain: } 1.1\end{array}$ & $\begin{array}{c}\text { GB: } 0.6 \\
\text { Green } \\
\text { plantain: } 0.5\end{array}$ & - & - & - & - & - & $\begin{array}{c}\text { GB: } 225.23 \mathrm{~g} \\
\text { Green plantain: } 259.20 \mathrm{~g}\end{array}$ \\
\hline Rabbani et al. [46] & - & - & - & - & - & - & - & - & - & - & - & $\begin{array}{l}\text { 1) Age 6-12 months: one-half to } \\
\text { one full fruit per day; } \\
\text { 2) Age 12-24 months: } 1-2 \text { fruits } \\
\text { 3) Age 24-36 months: } 3 \text { fruits }\end{array}$ \\
\hline Silva et al. [59] & Musa silver variety & - & 2.7 & 0.5 & 4.5 & 5.5 & - & - & - & - & - & - \\
\hline Cassettari et al. [54] & Musa spp. AAA & - & - & - & - & - & 4.4 & - & - & - & 7.8 & $30 \mathrm{~g}$ \\
\hline
\end{tabular}

${ }^{a}$ Evaluated available starch (\%): UBM: $53.2 \pm 1.2$; UBS: $16.8 \pm 0.9 ;{ }^{b}$ Evaluated phenolic compounds (7.50 \pm 1.73 mg GAE/g); ${ }^{\mathrm{c}}$ RS: Resistant starch; ${ }^{\mathrm{d}}$ DB: Dry basis; ${ }^{\mathrm{e}}$ RBF: Raw green banana flour; ${ }^{\mathrm{f}} \mathrm{CBF}$ : Cooked Banana flour; ${ }^{\mathrm{g}}$ UBM: Unripe banana mass (UBM); ${ }^{\mathrm{h}}$ UBS: Unripe banana starch. 
The lipid content in green banana products ranged from $0.43 \%$ to $17.59 \%[49,52,53,55]$ in green banana flour and it ranged from $0.1 \%$ to $0.5 \%$ in green banana pulp $[42,47,59]$. Regarding the protein content, the green banana flour presented from $1.88 \%$ to $19.1 \%$ [49,52,53,55], and the green banana pulp presented from $1.67 \%$ to $2.73 \%$ of protein $[47,59]$. As we mentioned before the large difference between the lipid and protein content in green banana flour is mainly related to the moisture content (that was not mentioned in the studies), and also related to the variety of banana, climate and soil of harvest, steps of flour production, and stage of maturation of the banana. However, only four studies mentioned the stage of maturation of green banana. Three of them used stage 1 (totally green) of maturation [42,50,60], and one referred to the maturation stage as "15 weeks" [49]. The others only mentioned that they used green banana.

In the production of the green banana product, traditionally stage 1 of banana maturation is used since it presents high antioxidant compounds, high starch, and low sugar contents. These characteristics are essential to promote health benefits that could lead GB as functional food characterization $[38,70]$. Only the study performed by Eleazu et al. [55] presented the amount of phenolic compounds (7.5 mg GAE/g), since most of the benefits attributed to green banana products consumption are associated with its RS content [28], justifying the few numbers of the studies evaluating the phenolic compounds in the potential health benefits. Phenolic compounds present in fruits are highlighted due to their potential antioxidant effects, which are related to the reduction of the risk of diseases caused by oxidative stress, especially in chronic diseases [82-85]. Antioxidants can be beneficial in several diseases prevention and treatment since they can play a protective role in the prevention of reactive oxygen species (ROS), mediated damage to the cells and tissues, preventing the harmful action of free-radicals on DNA, proteins, and lipids [86]. Also, they present protective properties against degenerative diseases such as Alzheimer, Parkinson, cancer, and cardiovascular diseases [87]. Eleazu et al. [55] mentioned that phenolics present potential antioxidant activity and that they can act on carbohydrate metabolism involving the inhibition of $\alpha$-glucosidase and $\alpha$-amylase (enzymes in charge of digestion of dietary carbohydrates to glucose). The authors also mentioned that GBs higher phenolic amount incorporated to the feed compared with the standard rat feed could explain the higher antidiabetic action found in the study [55].

Anyasi et al. [9] studied the phenolic profile of GBF. Of the phenolic compounds examined by the authors, catechin, gallic acid, and epigallocatechin were not detected, different from the data found in other studies $[88,89]$ that indicated the presence of gallic acid and catechin in GB obtained from other countries. The flavonoids epicatechin and myricetin 3-O-rhamnosyl-glucoside were detected in different concentrations in GB [9]. It is necessary to mention that, according to Gallani [90], the total phenolic content in ripened banana decreased when stored in refrigerated conditions $\left(4^{\circ} \mathrm{C}\right)$ for 15 days. The author stated that the total phenolic content could be influenced by many factors such as genotype, harvest time, and growing location. Another study [21] showed that the production of GBB, when cooked for $5 \mathrm{~min}$, presented higher levels of phenolic compounds $(p<0.05)$ compared with the GBB cooked for $10 \mathrm{~min}$. Refrigerated storage maintained the content of phenolics $(p<0.05)$. Since the authors used high temperatures to cook the GB samples, the activity of the enzyme related to the degradation of the polyphenolic compounds in phenolic compounds in bananas were inactivated, reducing the chance that total phenolic contents decrease during cold storage. Since we found only one study that evaluated GB phenolic compounds and their potential health benefit [55], further studies should be conducted to elucidate the mechanism and confirm this potential correlation.

Among the health benefits studied using green banana products, most of them were related to the gastrointestinal symptoms/diseases [41-46,48,54], followed by the glycemic/insulin metabolism [47,50, $53,56,60]$, weight control $[49,51,52,56]$, and renal and liver complications associated to diabetes [55,59]. Only one study did not confirm the health benefit proposed by the study [52]. It is important to emphasize that all the studies mentioned RS and fiber content of green banana as the main components to promote health benefits, despite the mention of phenolics and other potentially bioactive compounds. 
All the studies performed with children used green banana pulp/biomass [44-46,48,54]. The dose used ranged from $30 \mathrm{~g}$ (in total) [54] to $30 \mathrm{~g}$ per $\mathrm{kg}$ of body weight [44,45]. One study did not use this amount of green banana pulp in grams [46]. They referred the amount of GB as: For children aged 6-12 months, the recommended quantity ranged from one-half to one fruit daily; for 12-24 months, one to two fruits daily; and for 24-36 months, three fruits per day [46]. For adults, the studies performed with GBF used different amounts (8 $\mathrm{g}$ of GBF [60]; 20-36.3 $\mathrm{g}$ [51,52]; $24 \mathrm{~g}$ [49]; $30 \mathrm{~g}$ [43]; 54-81 g [50]). Only one study [47] conducted with adults used green banana pulp (GBP). The amount used in the study ranged from $225 \mathrm{~g}$ to $260 \mathrm{~g}$ of GBP [47]. In the studies conducted with rats, the daily dose ranged from $14 \mathrm{~g}$ [41] to $17 \mathrm{~g}$ [53] of green banana flour. When used the green banana pulp in rats, the dose was $1.3 \mathrm{~g}$ [42].

It is important to emphasize the need to standardize some relevant points as the dose/effect to different age groups and different health effects considering the variety of the green banana, the ripeness level. It is also relevant to study the health effects of green banana products when used as an ingredient of a potential "functional food" after the production of the meal, in which can be included manipulation and cook steps.

In addition to the aspects discussed regarding GB and health, there is a consensus about the relationship between diet, environmental sustainability, and human health. Agriculture presents increasingly global impacts on health, sustainability, diet, and environment [91]. As we mentioned before, the possibility of reduction of banana production waste/lost can significantly impact on health, and it was mentioned by most of the studies evaluated. In addition to the GB, other nonconventional food discarded as wastes from the banana production can be explored, such as banana pseudostem and banana flower, aiming to reduce the environmental damage and improving the sustainability [86] and contributing to the nutritional quality of the diet and reducing the hunger to the low-income population.

\subsection{Risk of bias}

We found heterogenicity between the studies: Eighteen had a low risk of bias and two had moderate risk. Three studies did not present the characterization of the products analyzed in detail $[41,42,54]$. Moreover, all studies specified the methods of analysis which were approved by the Codex Alimentariusand/or AOAC. All the studies answered its main question with the quantitative and well-described presentation of the health benefit analyzed (Table 3).

Table 3. Summary of risk of bias assessment.

\begin{tabular}{ccc}
\hline Reference & Risk of Bias & Risk Percentage \\
\hline Best, Lewis, and Nasser (1984) [41] & Moderate & $\mathbf{6 6 . 6 \%}$ \\
Dunjic et al. (1993) [42] & Moderate & $\mathbf{6 6 . 6 \%}$ \\
Rabbani et al. (2001) [44] & Low & $\mathbf{1 0 0 \%}$ \\
Langkilde, Champ, and & Low & $\mathbf{1 0 0 \%}$ \\
Andersson (2002) [43] & & \\
Rabbani et al. (2004) [45] & Low & $\mathbf{1 0 0 \%}$ \\
Bahado-Singh et al. (2006) [47] & Low & $\mathbf{1 0 0 \%}$ \\
Alvarzs-Acosta et al. (2009) [48] & Low & $\mathbf{1 0 0 \%}$ \\
Rabbani et al. (2010) [46] & Low & $\mathbf{1 0 0 \%}$ \\
Ble-Castillo et al. (2010) [49] & Low & $\mathbf{8 8 . 8 \%}$ \\
Menezes et al. (2010) [50] & Low & $\mathbf{1 0 0 \%}$ \\
Silva et al. (2014) [51] & Low & $\mathbf{1 0 0 \%}$ \\
Eleazu and Okafor (2015) [55] & Low & $\mathbf{8 8 . 8 \%}$ \\
Dan et al. (2015) [53] & Low & $\mathbf{8 8 . 8 \%}$ \\
Silva et al. (2015) [52] & Low & $\mathbf{1 0 0 \%}$ \\
Sardá et al. (2016) [60] & Low & $\mathbf{1 0 0 \%}$ \\
Silva et al. (2016) [59] & Low & $\mathbf{1 0 0 \%}$ \\
Arun et al. (2017) [56] & Low & $\mathbf{1 0 0 \%}$ \\
Cassettari et al. (2019) [54] & Low & $\mathbf{8 8 . 8 \%}$ \\
\hline
\end{tabular}




\section{Conclusions}

Overall, the studies showed the health benefits using green banana products, most of them related to the gastrointestinal symptoms/diseases, followed by the glycemic/insulin metabolism, weight control, and renal and liver complications associated to diabetes, most of the studies using green banana flour. The children group studies showed that green banana pulp influenced both diarrhea and constipation improvement. In healthy adults' group, GBF increased satiety and influenced glucose homeostasis, as same as the GBP and GB starch. Considering type 2 diabetes adults, studies showed a reduction of body weight and increase insulin sensitivity with GBF consumption. Among overweight women, GBF consumption improved anthropometric (weight and body composition), lipid profile, and inflammatory parameters. However, there is no standardization regarding dose/effect to different age groups and different health effects considering the variety of the green banana, and the ripeness level. It is also important to emphasize that few studies well characterize the chemical composition of the green banana product used. Further studies are relevant to evaluate if the health effects of green banana products remain when used as an ingredient of a potential "functional food" after the production of the food product.

Therefore, it is essential to present better detailing of the GB product associated with their health effects considering all of the raw-material characteristics, including production, storage, dose-response, and chemical characteristics. Considering the relationship between diet, environmental, economy, sustainability, and human health, the possibility of reduction of banana production waste/lost can probably present a significant impact on health. In addition to the GB, other nonconventional food from the banana production can be explored, aiming to reduce the environmental damage and improving the sustainability, contributing to the nutritional quality of the diet and reducing the hunger to a low-income population.

Supplementary Materials: The following are available online at http://www.mdpi.com/2072-6643/11/6/1222/s1, Figure S1: Distribution of studies within countries.

Author Contributions: Conceptualization, R.P.Z., A.L.F., B.R.d.L., R.F.R.R. and V.C.G.; methodology, R.P.Z., A.L.F., and B.R.d.L.; formal analysis, R.P.Z., A.L.F., B.R.d.L., R.F.R.R., and V.C.G.; investigation, R.P.Z., A.L.F., B.R.d.L., R.F.R.R. and V.C.G.; resources, R.P.Z., and V.C.G.; writing - original draft preparation, R.P.Z., A.L.F., B.R.d.L., R.F.R.R., and V.C.G.; writing-review and editing, R.P.Z., A.L.F., B.R.d.L., R.F.R.R. and V.C.G.; visualization, R.P.Z., A.L.F., B.R.d.L., R.F.R.R. and V.C.G.; supervision, R.P.Z.; project administration, R.P.Z. and V.C.G.; funding acquisition, V.C.G.

Funding: This work was supported by Fundação de Apoioà Pesquisa do Distrito Federal (FAPDF - No 0193.001036/2015).

Conflicts of Interest: The authors declare no conflict of interest.

\section{Appendix A}

Table A1. Database search strategy.

\begin{tabular}{|c|c|}
\hline Database & Search (September 17, 2018) \\
\hline PubMed & 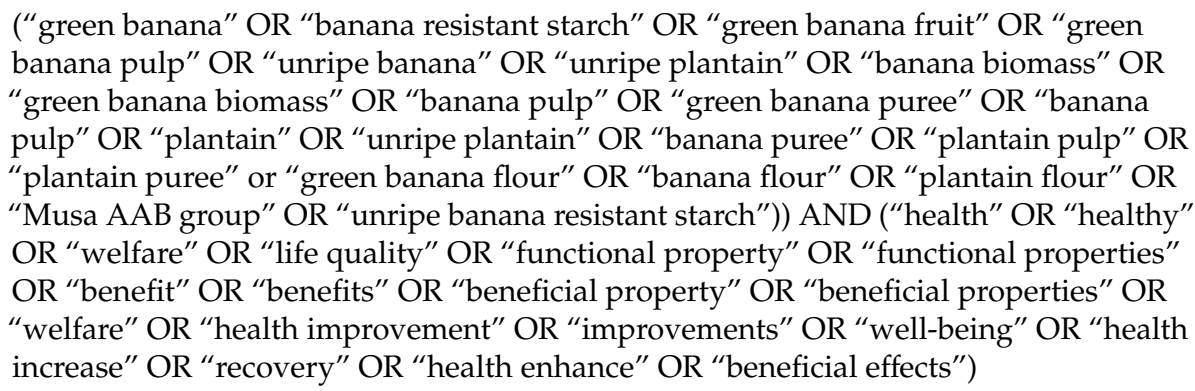 \\
\hline
\end{tabular}


Table A1. Cont.

\begin{tabular}{|c|c|}
\hline Database & Search (September 17, 2018) \\
\hline EMBASE & 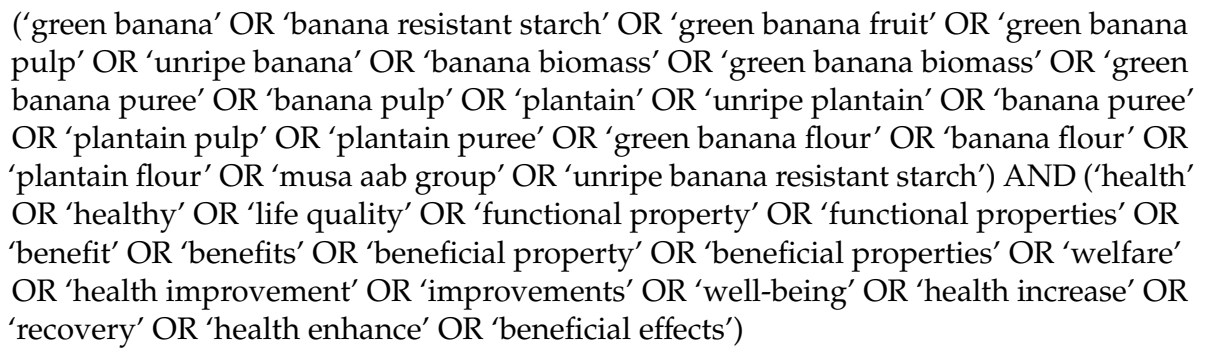 \\
\hline Scopus & $\begin{array}{l}\text { ( ( ALL ( ' green AND banana' OR ' banana AND resistant AND starch' OR ‘ green } \\
\text { AND banana AND fruit' OR ' green AND banana AND pulp' OR ' unripe AND } \\
\text { banana' OR ' banana AND biomass' OR ' green AND banana AND biomass' ) ) OR ( } \\
\text { ALL ( ' green AND banana AND puree' OR ' banana AND pulp' OR ' plantain' OR ' } \\
\text { unripe AND plantain' OR ' banana AND puree' OR ' plantain AND pulp' OR ' } \\
\text { plantain AND puree' OR ' green AND banana AND flour' ) ) OR ( ALL ( 'banana AND } \\
\text { flour' OR ' plantain AND flour' OR ' musa AND aab AND group' OR ' unripe AND } \\
\text { banana AND resistant AND starch' ) ) ) AND ( ( ALL ( ' health' OR ' healthy' OR ' life } \\
\text { AND quality' OR ' functional AND property' OR ' functional AND properties' OR ' } \\
\text { benefit' OR ' benefits' OR ' beneficial AND property' OR ' beneficial AND properties' } \\
\text { OR ' welfare' ) ) OR ( ALL ( ' health AND improvement' OR ' improvements' OR' } \\
\text { well-being' OR ' health AND increase' OR ' recovery' OR ' health AND enhance' OR ' } \\
\text { beneficial AND effects' ) ) ) }\end{array}$ \\
\hline Web of Science & $\begin{array}{l}\text { ((("green banana" OR "banana resistant starch" OR "green banana fruit" OR "green } \\
\text { banana pulp" OR "unripe banana" OR "unripe plantain" OR "banana biomass" OR } \\
\text { "green banana biomass" OR "banana pulp" OR "green banana puree" OR "banana } \\
\text { pulp" OR "plantain" OR "unripe plantain" OR "banana puree" OR "plantain pulp" OR } \\
\text { "plantain puree" or "green banana flour" OR "banana flour" OR "plantain flour" OR } \\
\text { "Musa AAB group" OR "unripe banana resistant starch")) AND ("health" OR "healthy" } \\
\text { OR "welfare" OR "life quality" OR "functional property" OR "functional properties" } \\
\text { OR "benefit" OR "benefits" OR "beneficial property" OR "beneficial properties" OR } \\
\text { "welfare" OR "health improvement" OR "improvements" OR "well-being" OR "health } \\
\text { increase" OR "recovery" OR "health enhance" OR "beneficial effects")) }\end{array}$ \\
\hline Google Scholar & (green banana and health benefits) \\
\hline
\end{tabular}




\section{Appendix B}

Table A2. Quality criteria of the studies selected for the systematic review about health benefits associated with ingestion of green banana.

\begin{tabular}{|c|c|c|c|c|c|c|c|c|c|c|}
\hline Reference & $\begin{array}{l}\text { Were the } \\
\text { Analyzed } \\
\text { Products } \\
\text { and Meals } \\
\text { Characterized } \\
\text { in Detail? }\end{array}$ & $\begin{array}{l}\text { Was the } \\
\text { Method of } \\
\text { Health } \\
\text { Benefit } \\
\text { Association } \\
\text { Analysis } \\
\text { Specified? }\end{array}$ & $\begin{array}{l}\text { Was the } \\
\text { Method Used } \\
\text { Certified/ } \\
\text { Validated by } \\
\text { Codex and/or } \\
\text { AOAC? }\end{array}$ & $\begin{array}{l}\text { Was the Result } \\
\text { of Health } \\
\text { Benefit } \\
\text { Determined } \\
\text { Quantitatively? }\end{array}$ & $\begin{array}{l}\text { Were the Methods of } \\
\text { Consumption of } \\
\text { Green Banana or } \\
\text { Sample } \\
\text { Homogenization of } \\
\text { the Study Samples } \\
\text { Described? }\end{array}$ & $\begin{array}{c}\text { Was the } \\
\text { Experimental } \\
\text { Design } \\
\text { Appropriate? }\end{array}$ & $\begin{array}{l}\text { Was the } \\
\text { Statistical } \\
\text { Adequate to } \\
\text { the Purpose } \\
\text { of the Study? }\end{array}$ & $\begin{array}{l}\text { Did the } \\
\text { Results } \\
\text { Answer the } \\
\text { Main } \\
\text { Question? }\end{array}$ & $\begin{array}{l}\text { Were the } \\
\text { Health } \\
\text { Benefits or Its } \\
\text { Absence Well } \\
\text { Described? }\end{array}$ & $\begin{array}{c}\text { Percentage of Positive } \\
\text { Answers (Yes) for Each } \\
\text { Study that Attained the } \\
\text { Quality Criteria }\end{array}$ \\
\hline Best, Lewis and Nasser (1984) [41] & $\mathrm{N}$ & $\mathrm{Y}$ & $\mathrm{Y}$ & $\mathrm{Y}$ & $\mathrm{N}$ & $\mathrm{Y}$ & $\mathrm{N}$ & $\mathrm{Y}$ & $\mathrm{Y}$ & $66.6 \%$ \\
\hline Dunjic et al. (1993) [42] & $\mathrm{N}$ & $\mathrm{Y}$ & $\mathrm{Y}$ & $\mathrm{Y}$ & $\mathrm{N}$ & $\mathrm{Y}$ & $\mathrm{N}$ & $\mathrm{Y}$ & $\mathrm{Y}$ & $66.6 \%$ \\
\hline Rabbani et al. (2001) [44] & $\mathrm{Y}$ & $\mathrm{Y}$ & $\mathrm{Y}$ & $\mathrm{Y}$ & $\mathrm{Y}$ & $\mathrm{Y}$ & $\mathrm{Y}$ & $\mathrm{Y}$ & $\mathrm{Y}$ & $100 \%$ \\
\hline $\begin{array}{l}\text { Langkilde, Champ and } \\
\text { Andersson (2002) [43] }\end{array}$ & $\mathrm{Y}$ & $\mathrm{Y}$ & $\mathrm{Y}$ & $\mathrm{Y}$ & $\mathrm{Y}$ & $\mathrm{Y}$ & $\mathrm{Y}$ & $\mathrm{Y}$ & $\mathrm{Y}$ & $100 \%$ \\
\hline Rabbani et al. (2004) [45] & $\mathrm{Y}$ & $\mathrm{Y}$ & $\mathrm{Y}$ & $\mathrm{Y}$ & $\mathrm{Y}$ & $\mathrm{Y}$ & $\mathrm{Y}$ & $\mathrm{Y}$ & $\mathrm{Y}$ & $100 \%$ \\
\hline Bahado-Singh et al. (2006) [47] & $\mathrm{Y}$ & $\mathrm{Y}$ & $\mathrm{Y}$ & $\mathrm{Y}$ & $\mathrm{Y}$ & $\mathrm{Y}$ & $\mathrm{Y}$ & $\mathrm{Y}$ & $\mathrm{Y}$ & $100 \%$ \\
\hline Alvarez-Acosta et al. (2009) [48] & $\mathrm{Y}$ & $\mathrm{Y}$ & $\mathrm{Y}$ & $\mathrm{Y}$ & $\mathrm{Y}$ & $\mathrm{Y}$ & $\mathrm{Y}$ & $\mathrm{Y}$ & $\mathrm{Y}$ & $100 \%$ \\
\hline Rabbani et al. (2010) [46] & $\mathrm{Y}$ & $\mathrm{Y}$ & $\mathrm{Y}$ & $\mathrm{Y}$ & $\mathrm{Y}$ & $\mathrm{Y}$ & $\mathrm{Y}$ & $\mathrm{Y}$ & $\mathrm{Y}$ & $100 \%$ \\
\hline Ble-Castillo et al. (2010) [49] & $\mathrm{Y}$ & $\mathrm{Y}$ & $\mathrm{Y}$ & $\mathrm{Y}$ & $\mathrm{N}$ & $\mathrm{Y}$ & $\mathrm{Y}$ & $\mathrm{Y}$ & $\mathrm{Y}$ & $88.8 \%$ \\
\hline Menezes et al. (2010) [50] & $\mathrm{Y}$ & $\mathrm{Y}$ & $\mathrm{Y}$ & $\mathrm{Y}$ & $\mathrm{Y}$ & $\mathrm{Y}$ & $\mathrm{Y}$ & $\mathrm{Y}$ & $\mathrm{Y}$ & $100 \%$ \\
\hline Silva et al. (2014) [51] & $\mathrm{Y}$ & $\mathrm{Y}$ & $\mathrm{Y}$ & $\mathrm{Y}$ & $\mathrm{Y}$ & $\mathrm{Y}$ & $\mathrm{Y}$ & $\mathrm{Y}$ & $\mathrm{Y}$ & $100 \%$ \\
\hline Eleazu and Okafor (2015) [55] & $\mathrm{Y}$ & $\mathrm{Y}$ & $\mathrm{Y}$ & $\mathrm{Y}$ & $\mathrm{Y}$ & $\mathrm{N}$ & $\mathrm{Y}$ & $\mathrm{Y}$ & $\mathrm{Y}$ & $88.8 \%$ \\
\hline Dan et al. (2015) [53] & $\mathrm{Y}$ & $\mathrm{Y}$ & $\mathrm{Y}$ & $\mathrm{Y}$ & $\mathrm{N}$ & $\mathrm{Y}$ & $\mathrm{Y}$ & $\mathrm{Y}$ & $\mathrm{Y}$ & $88.8 \%$ \\
\hline Silva et al. (2015) [52] & $\mathrm{Y}$ & $\mathrm{Y}$ & $\mathrm{Y}$ & $\mathrm{Y}$ & $\mathrm{Y}$ & $\mathrm{Y}$ & $\mathrm{Y}$ & $\mathrm{Y}$ & $\mathrm{Y}$ & $100 \%$ \\
\hline Sardá et al. (2016) [60] & Y & Y & Y & Y & Y & Y & Y & Y & Y & $100 \%$ \\
\hline Silva et al. (2016) [59] & $\mathrm{Y}$ & $\mathrm{Y}$ & $\mathrm{Y}$ & $\mathrm{Y}$ & $\mathrm{Y}$ & $\mathrm{Y}$ & $\mathrm{Y}$ & $\mathrm{Y}$ & $\mathrm{Y}$ & $100 \%$ \\
\hline Arun et al. (2017) [56] & $\mathrm{Y}$ & $\mathrm{Y}$ & $\mathrm{Y}$ & $\mathrm{Y}$ & $\mathrm{Y}$ & $\mathrm{Y}$ & $\mathrm{Y}$ & $\mathrm{Y}$ & $\mathrm{Y}$ & $100 \%$ \\
\hline Cassettari et al. (2019) [54] & $\mathrm{N}$ & $\mathrm{Y}$ & $\mathrm{Y}$ & $\mathrm{Y}$ & $\mathrm{Y}$ & $\mathrm{Y}$ & $\mathrm{Y}$ & $\mathrm{Y}$ & $\mathrm{Y}$ & $88.8 \%$ \\
\hline
\end{tabular}




\section{Appendix C}

Table A3. Full-text articles excluded, with reasons.

\begin{tabular}{cc}
\hline Author, Year & Reason for Exclusion \\
\hline Brakohiapa et al. [92] & 2 \\
Clark and Manini [93] & 2 \\
Rabbani et al. [94] & 1 \\
Perera et al. [95] & 3 \\
Alegbejo and Ameh [96] & 2 \\
Fahrasmane, Parfait and Aurore [97] & 1 \\
Cassettari et al. [98] & 1 \\
Silva et al. [99] & 1 \\
Apostolopoulos et al. [38] & 1 \\
Putu, Fiastuti and Kurniarobbi [100] & 2 \\
Vieira et al. [101] & 3 \\
Izar et al. [102] & 1
\end{tabular}

Legend-Exclusion criteria: 1-reviews, letters, conference summaries, case reports, short communications and books $(n=3)$. 2-full article not found $(n=7)$. 3-article does not focus on analyzing the green banana health benefits $(n=2)$.

\section{References}

1. WHO. Diet, Nutrition and Prevention of Chronic Disease. Report of a WHO Study Group (WHO Technical Report Series 797); WHO: Geneva, Switzerland, 2003.

2. World Health Organization (WHO). Increasing Fruit and Vegetable Consumption to Reduce the Risk of Noncommunicable Diseases. Available online: http://www.who.int/elena/titles/fruit_vegetables_ncds/en/ (accessed on 12 September 2018).

3. World Health Organization. Promoting fruit and vegetable consumption around the world. Glob. Strateg. Diet Phys. Act. Heal. 2005, 1.

4. FAO. Banana Facts and Figures. Available online: http://www.fao.org/economic/est/est-commodities/ bananas/bananafacts/en/\#.XKzikZhKg2w (accessed on 9 April 2019).

5. Food and Agriculture Organization of the United Nations (FAOSTAT). Available online: http://www.fao.org/ faostat/en/\#data/QC/visualize (accessed on 12 September 2018).

6. Jiang, H.; Zhang, Y.; Hong, Y.; Bi, Y.; Gu, Z.; Cheng, L.; Li, Z.; Li, C. Digestibility and changes to structural characteristics of green banana starch during in vitro digestion. Food Hydrocoll. 2015, 49, 192-199. [CrossRef]

7. Alves, L.A.A.S.; Lorenzo, J.M.; Gonçalves, C.A.A.; Santos, A.B.; Heck, R.T.; Cichoski, A.J.; Campagnol, P.C.B. Production of healthier bologna type sausages using pork skin and green banana flour as a fat replacers. Meat Sci. 2016, 121, 73-78. [CrossRef]

8. Food and Agriculture Organization of the United Nations. Fruit and Vegetable Processing, 119th ed.; FAO: Rome, Italy, 1995.

9. Anyasi, T.A.; Jideani, A.I.O.; Mchau, G.R.A. Functional Properties and Postharvest Utilization of Commercial and Noncommercial Banana Cultivars. Compr. Rev. Food Sci. Food Saf. 2013, 12, 509-522. [CrossRef]

10. Zandonadi, R.P.; Botelho, R.B.A.; Gandolfi, L.; Ginani, J.S.; Montenegro, F.M.; Pratesi, R. Green Banana Pasta: An Alternative for Gluten-Free Diets. J. Acad. Nutr. Diet. 2012, 112, 1068-1072. [CrossRef]

11. Tapre, A.; Jain, R. Study of advanced maturity stages of banana. Int. J. Adv. Eng. Res. Stud. 2012, I, $272-274$.

12. Von Loesecke, H.W. Bananas-Harry W. Von Loesecke-Google Livros, 2nd ed.; Interscience Publishers: New York, NY, USA, 1950.

13. Mustaffa, R.; Osman, A.; Yusof, S.; Mohamed, S. Physico-chemical changes in Cavendish banana (Musa cavendishiiL var Montel) at different positions within a bunch during development and maturation. J. Sci. Food Agric. 1998, 78, 201-207. [CrossRef]

14. Fernandes, K.M.; Carvalho, V.D.; Cal-Vidal, J. Physical changes during ripening of silver bananas. J. Food Sci. 1979, 44, 1254-1255. [CrossRef] 
15. de Souza, N.C.O.; de Oliveira, L.D.L.; de Alencar, E.R.; Moreira, G.P.; dos Santos Leandro, E.; Ginani, V.C.; Zandonadi, R.P. Textural, physical and sensory impacts of the use of green banana puree to replace fat in reduced sugar pound cakes. LWT 2018, 89, 617-623. [CrossRef]

16. Emaga, T.H.; Andrianaivo, R.H.; Wathelet, B.; Tchango, J.T.; Paquot, M. Effects of the stage of maturation and varieties on the chemical composition of banana and plantain peels. Food Chem. 2007, 103, 590-600. [CrossRef]

17. Xie, C.; Chu, B.; He, Y. Prediction of banana color and firmness using a novel wavelengths selection method of hyperspectral imaging This study investigated the feasibility of using hyperspectral imaging for determining banana color. Food Chem. 2017, 245, 132-140. [CrossRef] [PubMed]

18. Lii, C.-Y.; Chang, S.-M.; Young, Y.-L. Investigation of the Physical and Chemical Properties of Banana Starches. J. Food Sci. 1982, 47, 1493-1497. [CrossRef]

19. Chávez-Salazar, A.; Bello-Pérez, L.A.; Agama-Acevedo, E.; Castellanos-Galeano, F.J.; Álvarez-Barreto, C.I.; Pacheco-Vargas, G. Isolation and partial characterization of starch from banana cultivars grown in Colombia. Int. J. Biol. Macromol. 2017, 98, 240-246. [CrossRef] [PubMed]

20. Borges, A.M.; Pereira, J.; de Lucena, E.M.P. Caracterização da farinha de banana verde Green banana flour characterization. Ciênc. Tecnol. Aliment 2009, 29, 333-339. [CrossRef]

21. Riquette, R.F.R.; Ginani, V.C.; dos Santos Leandro, E.; de Alencar, E.R.; Maldonade, I.R.; de Aguiar, L.A.; de Souza Acácio, G.M.; Mariano, D.R.H.; Zandonadi, R.P. Do production and storage affect the quality of green banana biomass? LWT 2019, 111, 190-203. [CrossRef]

22. Wall, M.M. Ascorbic acid, vitamin A, and mineral composition of banana (Musa sp.) and papaya (Carica papaya) cultivars grown in Hawaii. J. Food Compos. Anal. 2006, 19, 434-445. [CrossRef]

23. Suntharalingam, S.; Ravindran, G. Physical and biochemical properties of green banana flour. Plant Foods Hum. Nutr. 1993, 43, 19-27. [CrossRef] [PubMed]

24. Hettiaratchi, U.P.K.; Ekanayake, S.; Welihinda, J. Chemical compositions and glycemic responses to banana varieties. Int. J. Food Sci. Nutr. 2011, 62, 307-309. [CrossRef] [PubMed]

25. Dutra-de-Oliveira, J.E.; Marchini, J.S. Ciencias Nutricionais, 2nd ed.; Sarvier: São Paulo, Brazil, 2008.

26. Bodinham, C.L.; Frost, G.S.; Robertson, M.D. Acute ingestion of resistant starch reduces food intake in healthy adults. Br. J. Nutr. 2010, 103, 917. [CrossRef]

27. Choo, C.L.; Aziz, N.A.A. Effects of banana flour and $\beta$-glucan on the nutritional and sensory evaluation of noodles. Food Chem. 2010, 119, 34-40. [CrossRef]

28. Basso, C.; Silva, L.P.; Bender, A.B.B.; Silveira, F. da Effect of elevated contents of resistant starch: On the blood glucose and on the food acceptability. Rev. do Inst. Adolfo Lutz 2011, 70, 276-282.

29. Costa, E.L.; Alencar, N.M.M.; Rullo, G.S.R.; Taralo, R.L. Effect of green banana pulp on physicochemical and sensory properties of probiotic yoghurt. Food Sci. Technol. 2017, 37, 363-368. [CrossRef]

30. Sarawong, C.; Schoenlechner, R.; Sekiguchi, K.; Berghofer, E.; Ng, P.K.W. Effect of extrusion cooking on the physicochemical properties, resistant starch, phenolic content and antioxidant capacities of green banana flour. Food Chem. 2014, 143, 33-39. [CrossRef] [PubMed]

31. Anderson, A.K.; Guraya, H.S. Effects of microwave heat-moisture treatment on properties of waxy and non-waxy rice starches. Food Chem. 2006, 97, 318-323. [CrossRef]

32. Bezerra, C.V.; Amante, E.R.; de Oliveira, D.C.; Rodrigues, A.M.C.; da Silva, L.H.M. Green banana (Musa cavendishii) flour obtained in spouted bed-Effect of drying on physico-chemical, functional and morphological characteristics of the starch. Ind. Crops Prod. 2013, 41, 241-249. [CrossRef]

33. Izidoro, D.R.; Scheer, A.P.; Sierakowski, M.-R.; Haminiuk, C.W.I.C.W.I. Influence of green banana pulp on the rheological behaviour and chemical characteristics of emulsions (mayonnaises). LWT-Food Sci. Technol. 2008, 41, 1018-1028. [CrossRef]

34. Singh, B.; Singh, J.P.; Kaur, A.; Singh, N. Bioactive compounds in banana and their associated health benefits-A review. Food Chem. 2016, 206, 1-11. [CrossRef] [PubMed]

35. Yap, M.; Fernando, W.M.A.D.B.; Brennan, C.S.; Jayasena, V.; Coorey, R. The effects of banana ripeness on quality indices for puree production. LWT 2017, 80, 10-18. [CrossRef]

36. Alkarkhi, A.F.M.; bin Ramli, S.; Yong, Y.S.; Easa, A.M. Comparing physicochemical properties of banana pulp and peel flours prepared from green and ripe fruits. Food Chem. 2011, 129, 312-318. [CrossRef] 
37. Meneses, S.M.; Molina, D.A.R.; Vargas, H.J.L. Caracterización fisicoquímica y funcionalidad tecnológica de la fibra de banano íntegro verde Caracterización fisicoquímica y funcionalidad tecnológica de la fibra de banano íntegro verde (Cavendish valery) (Musa AAA cv. Musaceae)*. Rev. Lasallista Investig. 2016, 13, $23-30$. [CrossRef]

38. Apostolopoulos, V.; Antonipillai, J.; Tangalakis, K.; Ashton, J.F.; Stojanovska, L. Let's Go Bananas! Green Bananas and their Health Benefits. PRILOZI 2017, 38, 147-151. [CrossRef] [PubMed]

39. Moher, D.; Liberati, A.; Tetzlaff, J.; Altman, D.G. PRISMA Group Preferred Reporting Items for Systematic Reviews and Meta-Analyses: The PRISMA Statement. PLoS Med. 2009, 6, e1000097. [CrossRef] [PubMed]

40. European Food Safety Authority. Nutrition Applications: Regulations and Guidance|European Food Safety Authority. Available online: https://www.efsa.europa.eu/en/applications/nutrition/regulationsandguidance (accessed on 20 June 2018).

41. Best, R.; Lewis, D.A.; Nasser, N. The anti-ulcerogenic activity of the unripe plantain banana (Musa species). Br. J. Pharmacol. 1984, 82, 107-116. [CrossRef]

42. Dunjić, B.S.; Svensson, I.; Axelson, J.; Adlercreutz, P.; Ar'Rajab, A.; Larsson, K.; Bengmark, S. Green banana protection of gastric mucosa against experimentally induced injuries in rats. A multicomponent mechanism? Scand. J. Gastroenterol. 1993, 28, 894-898. [CrossRef] [PubMed]

43. Langkilde, A.M.; Champ, M.; Andersson, H. Effects of high-resistant-starch banana flour (RS2) on in vitro fermentation and the small-bowel excretion of energy, nutrients, and sterols: An ileostomy study. Am. J. Clin. Nutr. 2002, 75, 104-111. [CrossRef] [PubMed]

44. Rabbani, G.H.; Teka, T.; Zaman, B.; Majid, N.; Khatun, M.; Fuchs, G.J. Clinical studies in persistent diarrhea: Dietary management with green banana or pectin in Bangladeshi children. Gastroenterology 2001, 121, 554-560. [CrossRef]

45. Rabbani, G.H.; Teka, T.; Saha, S.K.; Zaman, B.; Majid, N.; Khatun, M.; Wahed, M.A.; Fuchs, G.J. Green banana and pectin improve small intestinal permeability and reduce fluid loss in Bangladeshi children with persistent diarrhea. Dig. Dis. Sci. 2004, 49, 475-484. [CrossRef]

46. Rabbani, G.H.; Larson, C.P.; Islam, R.; Saha, U.R.; Kabir, A. Green banana-supplemented diet in the home management of acute and prolonged diarrhoea in children: A community-based trial in rural Bangladesh. Trop. Med. Int. Heal. 2010, 15, 1132-1139. [CrossRef] [PubMed]

47. Bahado-Singh, P.S.; Wheatley, A.O.; Ahmad, M.H.; Morrison, E.Y.S.A.; Asemota, H.N. Food processing methods influence the glycaemic indices of some commonly eaten West Indian carbohydrate-rich foods. Br. J. Nutr. 2006, 96, 476-481. [PubMed]

48. Alvarez-Acosta, T.; León, C.; Acosta-González, S.; Parra-Soto, H.; Cluet-Rodriguez, I.; Rossell, M.R.; Colina-Chourio, J.A. Beneficial role of green plantain [Musa paradisiaca] in the management of persistent diarrhea: A prospective randomized trial. J. Am. Coll. Nutr. 2009, 28, 169-176. [CrossRef] [PubMed]

49. Ble-Castillo, J.L.; Aparicio-Trápala, M.A.; Francisco-Luria, M.U.; Córdova-Uscanga, R.; Rodríguez-Hernández, A.; Méndez, J.D.; Díaz-Zagoya, J.C. Effects of native banana starch supplementation on body weight and insulin sensitivity in obese type 2 diabetics. Int. J. Environ. Res. Public Health 2010, 7, 1953-1962. [CrossRef] [PubMed]

50. Menezes, E.W.; Dan, M.C.T.; Cardenette, G.H.L.; Goñi, I.; Bello-Pérez, L.A.; Lajolo, F.M. In Vitro Colonic Fermentation and Glycemic Response of Different Kinds of Unripe Banana Flour. Plant Foods Hum. Nutr. 2010, 65, 379-385. [CrossRef]

51. Tavares da Silva, S.; Araújo Dos Santos, C.; Marvila Girondoli, Y.; Mello de Azeredo, L.; Fernando de Sousa Moraes, L.; Keila Viana Gomes Schitini, J.; Flávio C de Lima, M.; Cristina Lopes Assis Coelho, R.; Bressan, J. Women with metabolic syndrome improve antrophometric and biochemical parameters with green banana flour consumption. Nutr. Hosp. 2014, 29, 1070-1080. [CrossRef]

52. da Silva, S.T.; dos Santos, C.A.; Carraro, J.C.C.; Rocha, J.L.M.; Bressan, J. Farinha de banana verde não altera perfil lipídico e inflamatório de mulheres com excesso de peso. O Mundo da Saúde 2015, 39, 174-181. [CrossRef]

53. Dan, M.C.T.; Cardenette, G.H.L.; Sardá, F.A.H.; Giuntini, E.B.; Bello-Pérez, L.A.; Carpinelli, Â.R.; Lajolo, F.M.; Menezes, E.W. Colonic Fermentation of Unavailable Carbohydrates from Unripe Banana and its Influence over Glycemic Control. Plant Foods Hum. Nutr. 2015, 70, 297-303. [CrossRef] [PubMed] 
54. Cassettari, V.M.G.; Machado, N.C.; de Arruda Lourenção, P.L.T.; Carvalho, M.A.; Ortolan, E.V.P. Combinations of laxatives and green banana biomass on the treatment of functional constipation in children and adolescents: A randomized study. J. Pediatr. 2019, 95, 27-33. [CrossRef]

55. Eleazu, C.O.; Okafor, P. Use of unripe plantain (Musa paradisiaca) in the management of diabetes and hepatic dysfunction in streptozotocin induced diabetes in rats. Interv. Med. Appl. Sci. 2015, 7, 9-16. [CrossRef] [PubMed]

56. Arun, K.B.; Thomas, S.; Reshmitha, T.R.; Akhil, G.C.; Nisha, P. Dietary fibre and phenolic-rich extracts from Musa paradisiaca inflorescence ameliorates type 2 diabetes and associated cardiovascular risks. J. Funct. Foods 2017, 31, 198-207. [CrossRef]

57. Coltro, L.; Karaski, T.U. Environmental indicators of banana production in Brazil: Cavendish and Prata varieties. J. Clean. Prod. 2019, 207, 363-378. [CrossRef]

58. Food and Agriculture Organization of the United Nations. Banana Market Review; Food and Agriculture Organization: Rome, Italy, 2017.

59. da Silva, A.R.; Cerdeira, C.D.; Brito, A.R.; Salles, B.C.C.; Ravazi, G.F.; de Oliveira Isac Moraes, G.; Rufino, L.R.A.; de Oliveira, R.B.S.; Santos, G.B. Green banana pasta diet prevents oxidative damage in liver and kidney and improves biochemical parameters in type 1 diabetic rats. Arch. Endocrinol. Metab. 2016, 60, 355-366. [CrossRef] [PubMed]

60. Sardá, F.A.H.; Giuntini, E.B.; Gomez, M.L.P.A.; Lui, M.C.Y.; Negrini, J.A.E.; Tadini, C.C.; Lajolo, F.M.; Menezes, E.W. Impact of resistant starch from unripe banana flour on hunger, satiety, and glucose homeostasis in healthy volunteers. J. Funct. Foods 2016, 24, 63-74. [CrossRef]

61. Menezes, E.W.; Tadini, C.C.; Tribess, T.B.; Zuleta, A.; Binaghi, J.; Pak, N.; Vera, G.; Dan, M.C.T.; Bertolini, A.C.; Cordenunsi, B.R.; et al. Chemical Composition and Nutritional Value of Unripe Banana Flour (Musa acuminata, var. Nanicão). Plant Foods Hum. Nutr. 2011, 66, 231-237. [CrossRef] [PubMed]

62. Borges, A.D.M.; Pereira, J.; Silva Júnior, A.; Lucena, E.M.P.D.; Sales, J.C.D. Estabilidade da pré-mistura de bolo elaborada com 60\% de farinha de banana verde. Ciência e Agrotecnologia 2010, 34, 173-181. [CrossRef]

63. Fasolin, L.H.; Almeida, G.D.; Castanho, P.S.; Netto-Oliveira, E.R. Biscoitos produzidos com farinha de banana: Avaliações química, física e sensorial. Ciência e Tecnol. Aliment. 2007, 27, 524-529. [CrossRef]

64. Liao, H.-J.; Hung, C.-C. Chemical composition and in vitro starch digestibility of green banana (cv. Giant Cavendish) flour and its derived autoclaved/debranched powder. LWT_Food Sci. Technol. 2015, 64, 639-644. [CrossRef]

65. Haslinda, W.H.; Cheng, L.H.; Chong, L.C.; Aziah, A.A.N. Chemical composition and physicochemical properties of green banana (Musa acuminata $\times$ balbisiana Colla cv. Awak) flour. Int. J. Food Sci. Nutr. 2009, 60, 232-239. [CrossRef]

66. da Mota, R.V.; Lajolo, F.M.; Cordenunsi, B.R.; Ciacco, C. Composition and Functional Properties of Banana Flour from Different Varieties. Starch-Stärke 2000, 52, 63-68. [CrossRef]

67. Juarez-Garcia, E.; Agama-Acevedo, E.; Sáyago-Ayerdi, S.G.; Rodríguez-Ambriz, S.L.; Bello-Pérez, L.A. Composition, Digestibility and Application in Breadmaking of Banana Flour. Plant Foods Hum. Nutr. 2006, 61, 131-137. [CrossRef]

68. Sardá, F.A.H.; de Lima, F.N.; Lopes, N.T.; Santos, A.D.O.; Tobaruela, E.D.C.; Kato, E.T.; Menezes, E.W. Identification of carbohydrate parameters in commercial unripe banana flour. Food Res. Int. 2016, 81, $203-209$. [CrossRef]

69. Pelissari, F.M.; Andrade-Mahecha, M.M.; Sobral, P.J.D.A.; Menegalli, F.C. Isolation and characterization of the flour and starch of plantain bananas (Musa paradisiaca). Starch-Stärke 2012, 64, 382-391. [CrossRef]

70. Vatanasuchart, N.; Butsuwan, P.; Narasri, W. Nutritional composition, in vitro starch digestibility and estimated glycemic index of three varieties of 'Kluai Namwa' banana (Musa sapientum L.) and its products. Maejo Int. J. Sci. Technol. 2015, 9, 265-277.

71. Charnchai, P.; Jantama, S.S.; Prasitpuriprecha, C.; Kanchanatawee, S.; Jantama, K.; Malcata, F. Effects of the Food Manufacturing Chain on the Viability and Functionality of Bifidobacterium animalis through Simulated Gastrointestinal Conditions. PLoS ONE 2016, 11, e0157958. [CrossRef]

72. Agama-Acevedo, E.; Nuñez-Santiago, M.C.; Alvarez-Ramirez, J.; Bello-Pérez, L.A. Physicochemical, digestibility and structural characteristics of starch isolated from banana cultivars. Carbohydr. Polym. 2015, 124, 17-24. [CrossRef] [PubMed] 
73. do Prado Cordoba, L.; da Silva, R.G.; de Souza Gomes, D.; Schnitzler, E.; Waszczynskyj, N. Brazilian green banana. J. Therm. Anal. Calorim. 2018, 134, 2065-2073. [CrossRef]

74. Fuentes-Zaragoza, E.; Riquelme-Navarrete, M.J.; Sánchez-Zapata, E.; Pérez-Álvarez, J.A. Resistant starch as functional ingredient: A review. Food Res. Int. 2010, 43, 931-942. [CrossRef]

75. Zhang, P.; Hamaker, B.R. Banana starch structure and digestibility. Carbohydr. Polym. 2012, 87, 1552-1558. [CrossRef]

76. Walter, M.; da SIlva, L.P.; Emanuelli, T. Resistant starch: Physico-chemical characteristics, physiological properties and quantification methodologies. Ciência Rural 2005, 35, 974-980. [CrossRef]

77. Tribess, T.B.; Hernández-Uribe, J.P.; Méndez-Montealvo, M.G.C.; Menezes, E.W.; Bello-Perez, L.A.; Tadini, C.C. Thermal properties and resistant starch content of green banana flour (Musa cavendishii) produced at different drying conditions. LWT-Food Sci. Technol. 2009, 42, 1022-1025. [CrossRef]

78. Wang, Y.; Zhang, M.; Mujumdar, A.S. Influence of green banana flour substitution for cassava starch on the nutrition, color, texture and sensory quality in two types of snacks. LWT_Food Sci. Technol. 2012, 47, 175-182. [CrossRef]

79. Müller, M.; Canfora, E.E.; Blaak, E.E.; Müller, M.; Canfora, E.E.; Blaak, E.E. Gastrointestinal Transit Time, Glucose Homeostasis and Metabolic Health: Modulation by Dietary Fibers. Nutrients 2018, 10, 275. [CrossRef]

80. Elleuch, M.; Bedigian, D.; Roiseux, O.; Besbes, S.; Blecker, C.; Attia, H. Dietary fibre and fibre-rich by-products of food processing: Characterisation, technological functionality and commercial applications: A review. Food Chem. 2011, 124, 411-421. [CrossRef]

81. FAO. Guidelines for Use of Nutrition and Health Claims; FAO: Geneva, Switzerland, 2009; pp. 1-8.

82. Kubola, J.; Siriamornpun, S. Phytochemicals and antioxidant activity of different fruit fractions (peel, pulp, aril and seed) of Thai gac (Momordica cochinchinensis Spreng). Food Chem. 2011, 127, 1138-1145. [CrossRef] [PubMed]

83. Deng, G.-F.; Lin, X.; Xu, X.-R.; Gao, L.-L.; Xie, J.-F.; Li, H.-B. Antioxidant capacities and total phenolic contents of 56 vegetables. J. Funct. Foods 2013, 5, 260-266. [CrossRef]

84. de Carvalho-Silva, L.B.; Dionísio, A.P.; da Silva Pereira, A.C.; Wurlitzer, N.J.; de Brito, E.S.; Bataglion, G.A.; Brasil, I.M.; Eberlin, M.N.; Liu, R.H. Antiproliferative, antimutagenic and antioxidant activities of a Brazilian tropical fruit juice. LWT-Food Sci. Technol. 2014, 59, 1319-1324. [CrossRef]

85. Siriamornpun, S.; Weerapreeyakul, N.; Barusrux, S. Bioactive compounds and health implications are better for green jujube fruit than for ripe fruit. J. Funct. Foods 2015, 12, 246-255. [CrossRef]

86. Ramu, R.; Shirahatti, P.; Anilakumar, K.; Nayakavadi, S.; Zameer, F.; Dhananjaya, B.; Nagendra Prasad, M. Assessment of nutritional quality and global antioxidant response of banana (Musa sp. CV. Nanjangud Rasa Bale) pseudostem and flower. Pharmacogn. Res. 2017, 9, 74. [CrossRef]

87. Abdel-Hameed, E.-S.S. Total phenolic contents and free radical scavenging activity of certain Egyptian Ficus species leaf samples. Food Chem. 2009, 114, 1271-1277. [CrossRef]

88. Bennett, R.N.; Shiga, T.M.; Hassimotto, N.M.A.; Rosa, E.A.S.; Lajolo, F.M.; Cordenunsi, B.R. Phenolics and Antioxidant Properties of Fruit Pulp and Cell Wall Fractions of Postharvest Banana (Musa acuminata Juss.) Cultivars. J. Agric. Food Chem. 2010, 58, 7991-8003. [CrossRef]

89. Borges, C.V.; de Oliveira Amorim, V.B.; Ramlov, F.; da Silva Ledo, C.A.; Donato, M.; Maraschin, M.; Amorim, E.P. Characterisation of metabolic profile of banana genotypes, aiming at biofortified Musa spp. cultivars. Food Chem. 2014, 145, 496-504. [CrossRef] [PubMed]

90. Galani, J.H.Y.; Patel, J.S.; Patel, N.J.; Talati, J.G. Storage of Fruits and Vegetables in Refrigerator Increases their Phenolic Acids but Decreases the Total Phenolics, Anthocyanins and Vitamin C with Subsequent Loss of their Antioxidant Capacity. Antioxidants 2017, 6, 59. [CrossRef]

91. Tilman, D.; Clark, M. Global diets link environmental sustainability and human health. Nature 2014, 515, 518-522. [CrossRef]

92. Brakohiapa, L.A.; Quaya, I.K.; Amoah, A.G.; Harrison, E.K.; Kennedy, D.O.; Kido, Y.; Ofei, E. Noguchi Memorial Institute for Medical Research; University of Ghana: London, UK, 2001.

93. Clark, B.C.; Manini, T.M. Sarcopenia != Dynapenia. J. Gerontol. Ser. A Biol. Sci. Med. Sci. 2008, 63, 829-834. [CrossRef] [PubMed]

94. Rabbani, G.H.; Ahmed, S.; Hossain, M.I.; Islam, R.; Marni, F.; Akhtar, M.; Majid, N. Green Banana Reduces Clinical Severity of Childhood Shigellosis. Pediatr. Infect. Dis. J. 2009, 28, 420-425. [CrossRef] [PubMed] 
95. Perera, A.; Meda, V.; Tyler, R.T. Resistant starch: A review of analytical protocols for determining resistant starch and of factors affecting the resistant starch content of foods. Food Res. Int. 2010, 43, 1959-1974. [CrossRef]

96. Alegbejo, J.O.; Ameh, D.A. Glycaemic Index of Market Plantain in Healthy and Diabetic Subjects | Request PDF. J. Pure Appl. Microbiol. 2012, 6, 677-682.

97. Aurore, G.; Parfait, B.; Fahrasmane, L. Bananas, raw materials for making processed food products. Trends Food Sci. Technol. 2009, 20, 78-91. [CrossRef]

98. Cassettari, V.M.G. Análise da eficiência da biomassa de banana verde como complemento alimentar na melhora da constipação em pacientes funcionais e associada ao pós-operatório da Doença de Hirschdprung. Master's Thesis, Universidade Estadual Paulista Júlio de Mesquita Filho, São Paulo, Brazil, 2015.

99. dos Silva, A.A.; Barbosa, J.L., Jr.; Barbosa, M.I.M.J. Farinha de banana verde como ingrediente funcional em produtos alimentícios. Ciênc. Rural 2015, 45, 2252-2258. [CrossRef]

100. Putu, P.; Fiastuti, W.; Kurniarobbi, J. The Effect of Resistant Starch from Banana (musca spp) on Fatigue Response and Running Time During 10. 000 m Endurance Running. Adv. Sci. Lett. 2017, 23, 6782-6785. [CrossRef]

101. Vieira, C.R.; Laurides Ribeiro de Oliveira Lomeu, F.; de Castro Moreira, M.E.; Stampini Duarte Martino, H.; Ribeiro Silva, R. Clinical application of a cocoa and unripe banana flour beverage for overweight women with abdominal obesity: Prospective, double-blinded and randomized clinical trial. J. Food Biochem. 2017, 41, e12372. [CrossRef]

102. Izar, M.C.D.; Costa, E.S.; França, C.N.; Fonseca, F.A H.; Kato, J.; Bianco, H.T.; Freitas, T.; Fonseca, H.A.R.; Figueiredo -Neto, A.M. Beneficial effects of green banana biomass consumption in patients with pre-diabetes and diabetes: A randomized controlled trial. Atherosclerosis 2018, 275, e196. [CrossRef]

(C) 2019 by the authors. Licensee MDPI, Basel, Switzerland. This article is an open access article distributed under the terms and conditions of the Creative Commons Attribution (CC BY) license (http://creativecommons.org/licenses/by/4.0/). 